\title{
Canadian Association of Neurosciences Review: Polyglutamine Expansion Neurodegenerative Diseases
}

\author{
Ray Truant, Lynn A. Raymond, Jianrun Xia, Deborah Pinchev, Anjee Burtnik, \\ Randy Singh Atwal
}

\begin{abstract}
Since the early 1990s, DNA triplet repeat expansions have been found to be the cause in an ever increasing number of genetic neurologic diseases. A subset of this large family of genetic diseases has the expansion of a CAG DNA triplet in the open reading frame of a coding exon. The result of this DNA expansion is the expression of expanded glutamine amino acid repeat tracts in the affected proteins, leading to the term, Polyglutamine Diseases, which is applied to this sub-family of diseases. To date, nine distinct genes are known to be linked to polyglutamine diseases, including Huntington's disease, Machado-Joseph Disease and spinobulbar muscular atrophy or Kennedy's disease. Most of the polyglutamine diseases are characterized clinically as spinocerebellar ataxias. Here we discuss recent successes and advancements in polyglutamine disease research, comparing these different diseases with a common genetic flaw at the level of molecular biology and early drug design for a family of diseases where many new research tools for these genetic disorders have been developed. Polyglutamine disease research has successfully used interdisciplinary collaborative efforts, informative multiple mouse genetic models and advanced tools of pharmaceutical industry research to potentially serve as the prototype model of therapeutic research and development for rare neurodegenerative diseases.
\end{abstract}

RÉSUMÉ: Expansion de polyglutamines dans les maladies neurodégénératives. Depuis le début des années 1990, on a découvert qu'une expansion de répétitions de triplets d'ADN était la cause d'un nombre de plus en plus considérable de maladies neurologiques d'étiologie génétique. Un sousgroupe de cette grande famille de maladies génétiques possède une expansion d'un triplet CAG dans le cadre de lecture ouvert d'un exon codant. Cette expansion de l'ADN s'exprime au niveau de la protéine atteinte par une expansion de la séquence répétée d'un acide aminé, la glutamine, ce qui a donné lieu au terme de maladies à polyglutamines, terme qui s'applique à cette sous-famille de maladies. Jusqu 'à maintenant, ce phénomène a été observé dans neuf gènes différents en relation avec des maladies à polyglutamines dont la maladie de Huntington, la maladie de Machado-Joseph et l'amyotrophie spino-bulbaire ou maladie de Kennedy. La plupart des maladies à polyglutamines se classent au point de vue clinique parmi les ataxies spino-cérébelleuses. Nous discutons des découvertes récentes et des progrès de la recherche sur les maladies à polyglutamines et nous comparons ces différentes maladies qui ont un défaut génétique commun au point de vue biologie moléculaire. Nous traitons également de « drug design » pour une famille de maladies pour lesquelles plusieurs nouveaux outils de recherche ont été développés. La recherche sur les maladies à polyglutamines a bénéficié d'une collaboration interdisciplinaire et a utilisé avec succès plusieurs modèles génétiques de souris très informatifs ainsi que des outils de pointe de la recherche pharmaceutique et servira potentiellement de prototype en recherche et développement thérapeutique pour les maladies neurodégénératives rares.

Can. J. Neurol. Sci. 2006; 33: 278-291

Since the early analysis of the DNA sequence of the human genome, trinucleotide repeats have been noted and were thought to be common sequences found scattered throughout chromosomal DNA. ${ }^{1,2}$ Modern genetic approaches to disease gene linkage and cloning led to the first discovery of CAG triplet repeat expansion in the reading frame of the androgen receptor, the disease gene for x-linked spinobulbar muscular atrophy (SBMA, or Kennedy's disease). ${ }^{3}$ The next few years led to the discovery of CAG repeats and polyglutamine expansion in Huntington's disease ${ }^{4}$ and several spinocerebellar ataxias. ${ }^{5,6}$ The exact mechanism of CAG triplet repeat expansion is unknown, but can be recapitulated in vitro with a $\mathrm{C}-\mathrm{G}$ rich triplet repeat sequence, ${ }^{7}$ suggesting that the primary defect is dictated by the DNA structure of these sequences (Figure 1).

There exists some commonality, as well as many differences between these triplet repeat diseases. Triplet repeat expansions show both somatic and germ-line instability, ${ }^{8,9}$ where the sequences can expand in subsequent generations. This expansion of CAG repeats leads to earlier age of onset in subsequent generations of an affected patient's family, a phenomenon known

From the Department of Biochemistry and Biomedical Sciences (RT, JX, DP, AB RSA), McMaster University, Hamilton, ON; Division of Neuroscience, Department of Psychiatry and Brain Research Centre (LAR), Vancouver, BC, Canada. ReCEIVED MAY 26, 2005. ACCEPTED IN FINAL FORM APRIL 2, 2006. Reprint requests to: Ray Truant, Department of Biochemistry and Biomedical Sciences, McMaster University, HSC 4H45 1200 Main Street West, Hamilton, Ontario, L8N 3Z5, Canada. 


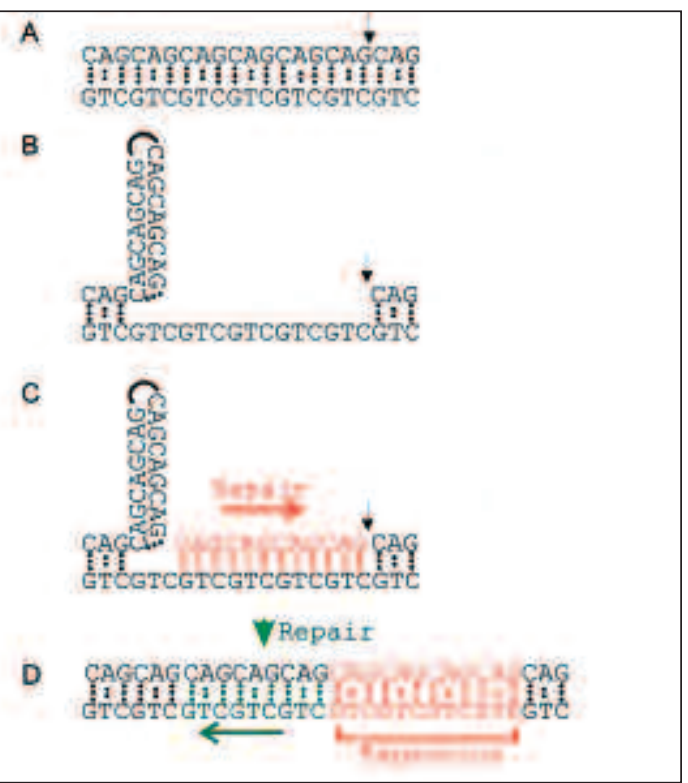

Figure 1: Model of CAG DNA repeat triplet expansion. A. CAG tract DNA is nicked on the phosphate backbone, leading to the formation of stable stem-loop structure due to high $G$-C content $(B)$, with the base of the stem forming an important $C-G$ pairing. $C$. Single-stranded DNA is filled in by the DNA repair machinery and DNA polymerase I, starting at the first $C$, hence maintaining the triplet codon frame. D. The DNA mismatch repair machinery fills in the bottom strand to result in the net expansion of the CAG tract.

as genetic anticipation. ${ }^{10}$ For most of these polyglutamine diseases, polyglutamine length varies inversely with age of onset, but not always with disease severity. The additional genetic factors and disease modifiers that affect disease severity are the recent focus of groups revisiting genetic family data. ${ }^{11,12}$ Anticipation can be affected by the parental origin of the mutant expansion, with paternal transmission leading to higher risk. ${ }^{13}$ Further genetic studies in human and mouse models reveal that most polyglutamine diseases are autosomal dominant, displaying a "gain-of-function" phenotype, where the function of the wildtype protein can be carried out by the mutant protein, but an additional polyglutamine-dependent function is involved in triggering pathology. ${ }^{14}$

Research into polyglutamine diseases has led to close scrutiny by other genetic disease researchers. Polyglutamine diseases such as Huntington's disease (HD) were among the first to have accurate genetic tests to predict the likelihood of disease and the age of onset, leading to studies of genetics and ethics of testing. ${ }^{15-17}$ Within a few years of discovery, transgenic mouse models were constructed that recapitulated several aspects of the human disease, ${ }^{18}$ and in some cases, multiple sophisticated models have been constructed to test hypotheses of pathogenicity. ${ }^{19-22}$ Recent techniques of pharmaceutical industrytype high-throughput chemical compound screens have been applied in attempts to find potential drug leads. ${ }^{23,24}$

Since the discovery of multiple polyglutamine disease proteins, this research has bifurcated into two paths: determining if there is a single, common gain-of-function of polyglutamine tracts in proteins, and the specific effects of polyglutamine tracts on the normal biological functions of these disease proteins. In 1993, the Nobel Laureate, Max Perutz, presented a biochemical theory of polyglutamine polar side group "zipper" interactions that would lead to intermolecular interactions and aggregation of protein. ${ }^{25}$ Indeed, protein aggregates of several polyglutamine disease proteins were detected in some patient brain samples, ${ }^{26}$ huntingtin mouse models, ${ }^{27,18}$ and more recently in real time using methods of live cell microscopy (Figure 2). ${ }^{28}$ One hypothesis is that aggregates of polyglutamine-expanded proteins lead to a universal toxic gain-of-function, such as the sequestration of critical transcription factors in the nucleus, ${ }^{14}$ or the immobilization of the polyglutamine disease protein into insoluble protein precipitates. These observations have led to the suggestion that polyglutamine diseases may be considered misfolded protein neurodegenerative diseases, analogous to misfolded proteins detected in Alzheimer's, Parkinson's and transmitted spongiform encephalopathy diseases. This has led to cross-talk in research between fields dedicated to "amyloid-like" neurodegenerative diseases. ${ }^{29}$ Another hypothesis is that normal, short polyglutamine tracts in proteins are normally unstructured and flexible components of a protein "scaffold", where the protein makes more than one protein-protein interaction and in turn, these interacting proteins can interact with each other, analogous to construction workers on a scaffold. In polyglutamine disease, the expanded glutamine tract takes on
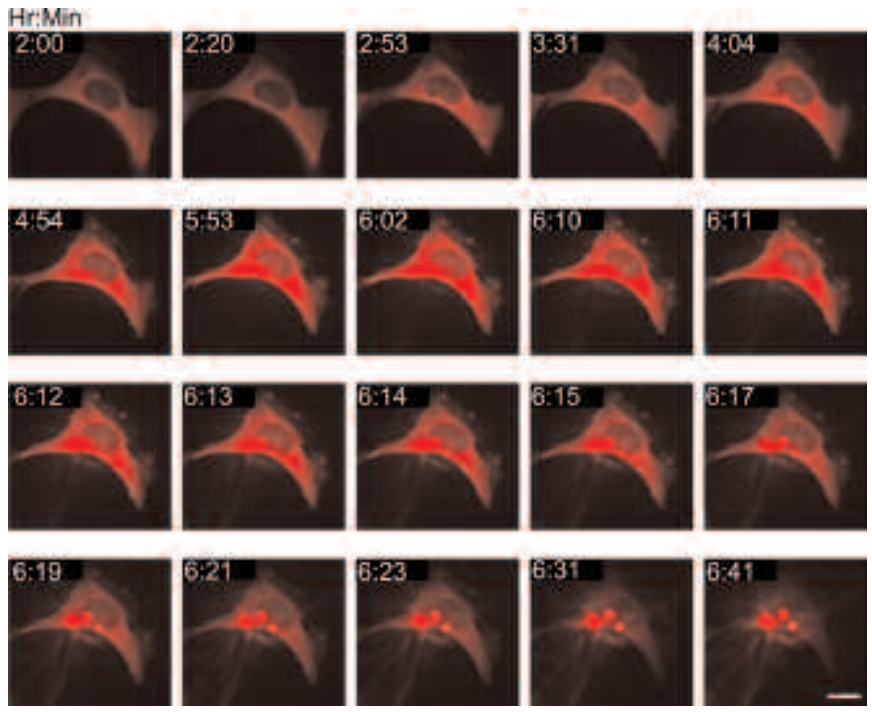

Figure 2: Dynamics of Polyglutamine Aggregation Initiation and Polymerization. Live cell time course fluorescence microscopy of huntingtin Q138 Exon1 (from juvenile-onset patient)-mRFP fusion expressed in STHdhQ7/Q7 cells. Over four hours, soluble huntingtin fragment accumulates in the cell until a minimum threshold concentration is reached, then rapid formation of inclusions is seen within minutes, and subsequent sequestration of remaining soluble Q138 huntingtin exon1. In this cell line, the formation of mutant huntingtin exon1 inclusions is seen to delay cell death over cells where no inclusions have formed. Scale bar is 10 um. Time in hours, minutes is in the top left corner of each frame. Full video can be viewed and downloaded at www.raytruantlab.ca 


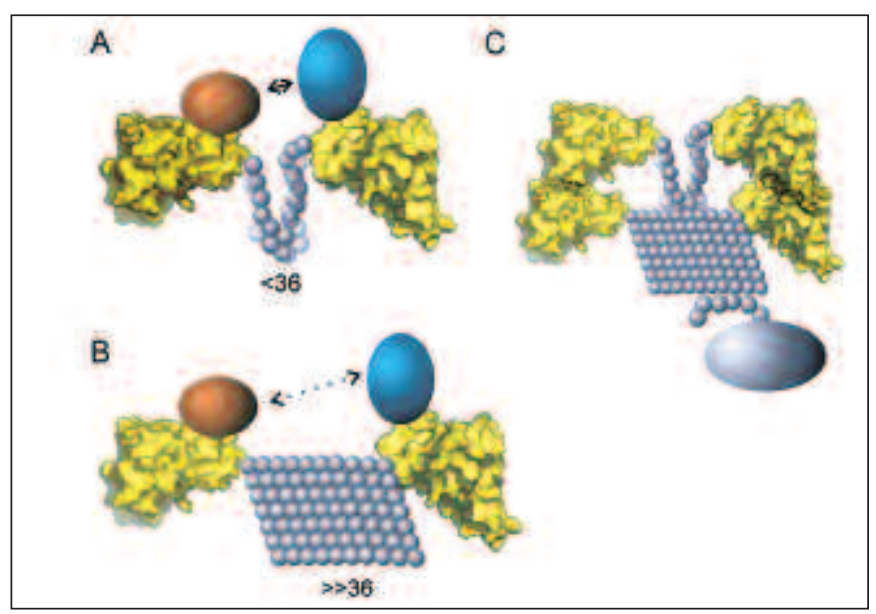

Figure 3: Models of Polyglutamine Induced Toxicity in Polyglutamine disease Proteins. A. Normal length polyglutamine tracts act as flexible components of a protein scaffold, a platform for important regulatory interactions between proteins involved in cell signaling or the normal biological function of the protein. B. Polyglutamine disease, the expanded polyglutamine tract gains structure, and can perturb the normal communication between bound proteins, leading to a perceived gain-of-function, or, allows the formation of new interactions with cellular factors. C. Potential mechanisms of genetic dominance over the wild-type allele protein, sequestration of the wild-type protein into mutant inclusions, and/or sequestration of glutamine-rich transcription factors essential for cell health as gain-of-function.

structure ${ }^{30}$ disrupting the protein scaffold, leading to a gain-offunction by impeding important protein intramolecular interactions leading to a molecular switch of regulation stuck in either the "on" or "off" position (Figure 3). This second scaffolddisruption model may also apply to other genetic diseases in which other amino acid tracts are expanded, such as polyalanine expansions of PABP2 in oculopharyngeal muscular dystrophy,31,32 the HOXA13 protein in hand-foot-genital syndrome $^{33}$ or within FOXL2 in Blepharophimosis syndrome. ${ }^{34}$

This review will summarize recent advancements, successes and controversies of this class of neurodegenerative diseases. Most advances in polyglutamine disease research have come from attempts to understand the normal biological function of the affected proteins, which help to infer the pathogenic trigger caused by the polyglutamine expansion. In the case of Huntington's disease, the research funded between government agencies and private charities has led to a new model of nonprofit pharmaceutical research and development towards the goal of a therapy.

\section{Huntington's Disease or Huntington's Chorea in the Clinic}

Huntington's disease (HD) is characterized by a triad of cognitive, behavioral and motor changes, usually with onset around middle age and progression over 15-20 years to death. Clinical features related to cognition and behavior include: subcortical dementia; personality changes such as irritability, increased aggression, or apathy, often accompanied by mood disorder and less commonly psychosis. Those features related to motor changes include extrapyramidal movement disorders typified by dyskinesias, motor incoordination, and postural instability that later evolves to severe bradykinesia and rigidity. ${ }^{35-37}$ Clinical manifestations result from selective neuronal dysfunction and loss, mainly of the striatum mediumsized spiny neurons in caudate and putamen nuclei; lesser and to a lesser extent in certain layers of the cortex, CA1 of the hippocampus, and some subcortical nuclei. ${ }^{37,38}$ Currently, therapy in HD is limited to treatment of symptoms, since no therapy has yet been proven to slow progression or delay onset of the disease. Agents that inhibit dopamine transmission are generally effective for suppressing chorea, but side effects such as sedation, bradykinesia and rigidity (both typical and atypical neuroleptics), or depression (for the dopamine-depleting agent tetrabenazine) limit their use. Mood and obsessive-compulsive disorders are treated with typical drugs. ${ }^{39}$ A deeper understanding of the normal function of the huntingtin protein, as well as the molecular mechanisms underlying pathogenesis of Huntington's disease, will facilitate development of therapies targeted toward modifying the disease course.

The typical length of the polyglutamine tract of the HD IT15 gene product in normal individuals is about 9-15 in length, and similar lengths are seen in normal alleles of SCA1,3, and DRPLA ${ }^{40}$ For late-onset $\mathrm{HD}$, disease is seen with polyglutamine expansions in the 36 or higher repeat range, and earlier onset is seen with longer expansions of 60-85 in length, where this expansion length can be used as an accurate predictor of age of onset. ${ }^{17}$ Juvenile cases can express huntingtin protein with very long repeats in excess of 100 polyglutamines. ${ }^{41}$ However, what is not known about HD and some other polyglutamine diseases is the significance of the 36 repeats of polyglutamine being the threshold of disease. ${ }^{42}$ This may relate to the biophysical and biochemical properties of 36 or more glutamines that are different from lower repeat lengths.

\section{The Huntington's Disease Protein, Huntingtin: Clues From HIPs, HAPs AND HYPs}

One of the typical questions from clinicians interested in the molecular biology of Huntington's disease is: what is the normal function of huntingtin protein? The answer is only being elucidated recently, through the use of protein-protein interaction studies with huntingtin, focusing on the biological functions of huntingtin-interacting proteins. Early studies defined unique huntingtin interacting proteins, such as the Huntingtin Interacting Proteins (HIPs), ${ }^{43}$ the Huntingtin Associated Proteins (HAPs), ${ }^{44}$ and Huntingtin Yeast-interacting Proteins (HYPs), ${ }^{45,46}$ but with a lack of known biological functions for most of these proteins. However, as more information was being uncovered about these interacting proteins, overlap in functions started appearing. ${ }^{47-51}$ Huntingtin is now seen as a protein whose biological functions include involvement in vesicular trafficking, i.e. the transport of lipid vesicles (endocytic, ${ }^{52}$ synaptic, ${ }^{53}$ lysosomal ${ }^{54}$ ) along microtubules, or the cell skeleton, via an energy-dependent motor machinery. ${ }^{55,56}$ At the early endosome, this interaction requires HAP40. ${ }^{57}$ Huntingtin has also been seen at the endoplasmic reticulum, and in the nucleus, ${ }^{58,59}$ and can dynamically traffic between these two compartments. ${ }^{28}$ While this may seem like many functions for one protein, the huntingtin 
protein is $350 \mathrm{KDa}$ in size, and is one of the larger nontransmembrane proteins known in the human proteome. The large size of huntingtin has been a major contributing factor to the technical difficulties in studying this protein, making expression and biochemical studies very challenging. The immediate goal of this line of HD research is to understand which of these activities is most important to triggering pathology in HD. Within the nucleus, huntingtin is thought to be involved in transcription modulation in response to the brainderived neurotrophic factor, BDNF, ${ }^{60-64}$ and the cyclic AMP response element binding protein, $\mathrm{CREB},{ }^{65,66}$ thus implicating huntingtin's potential role in signal transduction from the cytoplasm to the nucleus. In the cytoplasm, huntingtin has also been seen to be directly involved in the transport of BDNFcontaining vesicles. ${ }^{67}$

The connection between huntingtin and neurotrophic factors is important to understanding the molecular pathology of Huntington's disease. Huntingtin has been shown to be involved in programmed cell death, or apoptosis, ${ }^{68,69}$ and is proteolytically cleaved by the carboxy aspartyl proteases, or caspases involved in apoptosis. ${ }^{70}$ This work has suggested that striatal cells are triggered for death by mutant huntingtin by a molecular "suicide" mechanism gone wrong. In the brain, striatal cells do not produce significant quantities of BDNF, but rely on input of this critical factor from the cortical cells. Lack of transport of BDNF out of cortical cells, or lack of uptake via endocytosis by striatal cells, suggests that the alternative, "murder" hypothesis of the striatal cells by the cortical cells may induce striatal loss. ${ }^{71}$ One of the striking features of autopsied late-stage HD patient brains is the tremendous loss of the striatum, and up to $30 \%$ of total brain mass. ${ }^{37}$ These hypotheses of lowered BDNF levels are leading to radical gene therapeutic approaches in attempt to restore BDNF levels in HD-affected brains. ${ }^{72}$

\section{Huntingtin and Small Molecule Screening: On the Path TO A THERAPY}

Since 1999, many projects on huntingtin and polyglutamine diseases have been using modern state-of-the-art techniques employed successfully by the pharmaceutical industry, including high-throughput screening (HTS) of small chemical compounds. High-throughput screening involves simple assays that can be scaled to very large repetitive levels and hundreds of thousands of samples that can be performed continuously and robotically. The successes of this approach have led to screens for several diseases, and Food and Drug Administration (FDA) approved therapeutic drug compounds such as cyclooxygenase 1,2 inhibitors, (Roficoxib, Etoricoxib), ${ }^{73-74}$ antiviral compounds, ${ }^{75,76}$ and the Bcl-Abl tyrosine kinase inhibitor for the treatment of chronic myelogenous leukemia and gastrointestinal stromal tumors, Gleevec. ${ }^{77}$ Unlike these success stories however, polyglutamine disease researchers do not yet have a defined target to do precise screening and drug design. This is a tremendous challenge, as high-throughput screening with very large chemical libraries can be logistically difficult even when a very specific target is known, i.e. the ATP-binding pocket region of a kinase protein.

Initial screens against HD were targeted at compounds that prevent aggregation of polyglutamine in biochemical assays. ${ }^{23}$ These screens have led to the identification of small molecules and polypeptides that could inhibit polyglutamine-mediated aggregation in vitro, with a few that worked in vivo, but at relatively high effective concentrations. ${ }^{23,78,79}$ The problem with chemical compound screens as the starting point to drug discovery is that considerable time and finances must be in place to bring a compound to FDA approval. Pharmacological obstacles such as compound toxicity, solubility, stability and the ability to cross the blood/brain barrier are necessary considerations while the chemical derivatives must still maintain the desired activity. Modern numbers for lead compounds development to a drug are in the hundreds of millions of dollars and over a decade in time, which are difficult resources to obtain for such relatively rare diseases.

An alternative approach to broad chemical compound screens is to screen previously FDA-approved molecules for novel activities, or from libraries of known biologically active compounds. One such screen defined a single hit from this library of 2800 molecules: the p160ROCK rho associated kinase inhibitor, Y-27632, a molecule that could inhibit polyglutamine mediated aggregation of huntingtin protein fragments. ${ }^{80}$ This intriguing result suggested that factors in addition to polyglutamine expansion may have an effect on aggregation of huntingtin. Additionally, recent work in cell biological studies and the use of intracellularly expressed antibodies or "intrabodies" suggest that the polyproline region adjacent to the polyglutamine tract in huntingtin may be important in triggering aggregation. ${ }^{81,82}$ Another screen identified several pre-approved compounds, but at effective concentrations too high for practical use and are therefore characterized as potential lead compounds. ${ }^{83}$ Screens in Drosophila fly models identified the histone de-acetylase (HDAC) inhibitor family of compounds as suppressors of polyglutamine toxicity, implying a potentially important role of huntingtin activity in the nucleus at the level of transcription regulation. Histone de-acetylase inhibitors, also used as anti-tumor agents, show efficacy in HD fly models, primary neuronal cultures and mouse models. ${ }^{84-86}$ Another promising lead compound is $\mathrm{C} 2-8$, a sulfobenzoic acid derivative that shows neuroprotection against huntingtin toxicity at nanomolar concentrations. ${ }^{24}$ While the exact mechanism on C28 activity is not known, rather than preventing the onset of aggregation, C2-8 prevents the growth of small polyglutamine aggregates into large protein inclusions (Figure 2). ${ }^{24} \mathrm{~A}$ converse approach is to force mutant huntingtin into inclusions by the use to pro-inclusion compounds, such as B2 and B5, which do show protection against toxicity by mutant huntingtin and alpha synuclein in Parkinson's Disease cell models, but at high concentrations. ${ }^{87}$ While polyglutamine and its biophysical properties are a logical target for targeted drug design in polyglutamine diseases, successful therapies for other diseases often focus on signaling molecules, typically small, soluble molecules with kinase activity, amenable to inhibition by deliverable small chemical compounds. ${ }^{88}$

\section{InTracellular Signaling And Huntington's Disease}

If the expanded polyglutamine tract may not be the optimal target for drug design in HD and other polyglutamine diseases, well-established practical targets of drug design in disease which may lead to a combination therapy approach are signaling molecules such as serine, threonine or tyrosine kinases involved 
in sensor activation pathways, or nuclear hormone receptors. ${ }^{77} \mathrm{~A}$ good example of dedicated efforts in this respect are inhibitors of nuclear hormone receptors with broad applications in cancer treatment, cardiac disease, angiogenesis and asthma. ${ }^{89-93}$ Understanding the biological function of huntingtin means understanding any role of huntingtin in intracellular and intercellular signaling. The involvement of huntingtin in these signaling pathways and cascades not only elucidates the activities of normal huntingtin, but can help us understand the molecular pathological triggers of mutant huntingtin in HD. In one example, huntingtin is phosphorylated by the akt kinase/protein kinase $\mathrm{B}$ at serine 421. Post-translational modification of huntingtin at serine 421 can be induced by insulin growth factor 1 , inhibit neuronal cell death by mutant huntingtin and inhibit huntingtin aggregation. ${ }^{94}$ The switching on of akt kinase in mutant huntingtin mouse cells has been linked to the enhanced activation of the N-methyl-D-aspartate receptor. ${ }^{95}$ Excessive activation of the $\mathrm{N}$-methyl-D-aspartate receptor is a classic observation in HD leading to the theory of excitotoxicity, or over-activation of glutamate-type receptors leading to cell death. ${ }^{96-98}$ Huntingtin affects the signaling of the mGluR1 glutamate receptor through an associated HYP protein, Optineurin. ${ }^{99}$ The intriguing commonality of some of these experiments, and those previously mentioned for the p160ROCK inhibitor, ${ }^{80}$ is that kinase activators or inhibitors appear to be able to modulate polyglutamine-dependant aggregation of huntingtin, again suggesting that additional factors other than polyglutamine tract expansion may influence the presence of aggregated huntingtin protein.

Mutant huntingtin has also been seen to activate signaling by I kappa B kinase, ${ }^{100,101}$ and activate the JNK terminal kinase, an important step to triggering apoptosis. ${ }^{102}$ Calcium-mediated signaling is disrupted in HD mouse models, but is not restricted to neurons and can be detected in mutant huntingtin lymphoblasts, suggesting that huntingtin's involvement in calcium signaling may be a universal function in all cells. ${ }^{103-105}$ Disrupted calcium signaling is seen in another polyglutamine disease, spinocerebellar ataxia type 6 , where the polyglutamine expansion is in the alpha $1 \mathrm{~A}$ voltage-dependent calcium channel. ${ }^{106}$ Unlike most other polyglutamine diseases, the polyglutamine tract expansion in SCA6 is thought to result in a loss of function of the alpha $1 \mathrm{~A}$ voltage-dependent calcium channel. ${ }^{107}$

The inter-regulatory pathways that typically connect signaling cascades in cells provide several potential therapeutic targets for HD. The challenge to cell biologists will be to determine which of the signaling kinases, involved with huntingtin modification, are the result of cell stress due to mutant huntingtin expression, or direct pathways triggering mutant huntingtin-mediated cell death. Targeted inhibition of a signaling pathway critical to HD could prevent mutant huntingtin from triggering pathology by keeping it inactive. This concept has seen fruition in the case of spinal and bulbar muscular atrophy (SBMA), caused by polyglutamine expansion in the wellcharacterized androgen receptor.
Spinal and Bulbar Muscular Atrophy (SBMA): The Androgen Receptor. A Model for Polyglutamine Disease THERAPY?

Spinal and bulbar muscular atrophy (or Kennedy's Disease) is a late-onset progressive neurodegenerative disease affecting lower motor neurons and manifesting with proximal limb muscle weakness, fasticulations and bulbar movement. The late result of this disease is a progressive atrophy of muscle fibres and replacement with adipose tissue. Until recently, no specific treatment was available. Unlike the other polyglutamine diseases, SBMA primarily affects males, following a mode of Xlinked inheritance. Females typically exhibit a reduced pathology. The molecular basis for this disease at the genetic level became apparent when the gene mutation was identified as a CAG expansion in exon 1 of the androgen receptor (AR). ${ }^{3}$

In contrast to the other polyglutamine disease proteins, the exact biological function of the AR is well characterized. The AR is a steroid nuclear receptor, a ligand-dependent nuclear transcription factor that is essential for the development of the male fetus, male sexual characteristics and the maintenance of spermatogenesis. ${ }^{108}$ Like huntingtin, the AR has the ability to enter the nucleus. The precise genes that are activated and the co-factors required for transcription activation withe the AR are well known. Also as with huntingtin, and other polyglutamine diseases, polyglutamine expansion in the AR exhibits a gain-offunction, in that loss of the AR in males leads to feminization, but no neuropathy, in a disease termed Androgen Insensitivity Syndrome. ${ }^{109}$ This indicates that the polyglutamine expanded AR is capable of all the functions of the normal AR, but with an additional toxic function. ${ }^{14}$

The function of the AR as a transcription modulator involves both on and off mechanisms. These mechanisms include ligand binding and nuclear localization via a nuclear localization signal near the DNA binding domain as the "on" switch, and nuclear export via a nuclear export signal as the "off" switch. These signals are amino-acid sequences within the proteins that are used as recognition targets by other protein factors to move proteins into different cellular compartments, and are now being seen as important for regulation of transcription events and cell signaling. ${ }^{110}$ The role of ligand binding, specifically testosterone, in this mechanism is to inhibit the nuclear export signal, thus allowing the AR to accumulate in the nucleus at effective concentrations to activate transcription ${ }^{111}$ (Figure 4). In the absence of the ligand, the AR continuously traffics between the nucleus and the cytoplasm, but once bound to testosterone, enters the nucleus and does not exit due to inhibition of nuclear export.

In SBMA, the polymorphic polyglutamine region in the AR that is normally between 10 and 36 repeats is expanded to 40-62 repeats. ${ }^{3}$ Spinal and bulbar muscular atrophy neurons are seen to contain intranuclear inclusions of the AR and elevated nuclear AR levels, like some other polyglutamine diseases. ${ }^{112,113}$ The exact mechanism of toxicity of these nuclear inclusions is not clear, but as with huntingtin, it is thought to involve the sequestration of transcription factors, ${ }^{114}$ or the inhibition of normal proteolytic turnover of proteins. ${ }^{115}$ However, neither of these mechanisms explains the toxic specificity of polyglutamine-expanded proteins to specific neuronal 


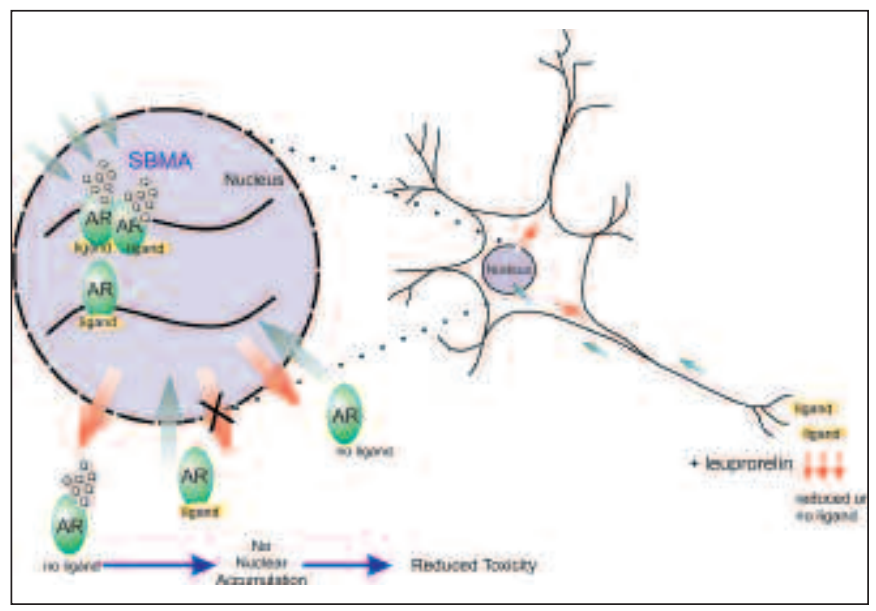

Figure 4: Model of the Androgen Receptor Function and Dysfunction in SBMA. The Androgen receptor is a nuclear hormone receptor, with nuclear localization and nuclear export signal sequences. The AR normally shuttles between the nucleus and cytoplasm in the absence of ligand, i.e. testosterone, but in the presence of ligand, nuclear export is inhibited, while nuclear import is unaffected, resulting in nuclear accumulation of AR to threshold levels for transcription activation of specific genes. In SBMA, polyglutamine-expanded AR is toxic, but only when retained in the nucleus by ligand, not in the absence or low levels of ligand. Testosterone release inhibitors, such as leuprorelin, reduce circulating testosterone levels resulting in inhibited AR nuclear signaling and hence polyglutamine-expanded $A R$ nuclear accumulation. In contrast, the androgen antagonist, flutamide, promotes nuclear translocation of AR, but has no therapeutic benefit in animal models of SBMA.

populations, despite ubiquitous expression, or even higher expression in cell types not lost during SBMA. In recent studies, lower motor neurons in mice were noted to have increased levels of nuclear polyglutamine expanded AR, but not necessarily in inclusions. ${ }^{112}$

There are cases where polyglutamine-expanded AR leads to an attenuated SBMA. For example, in female carriers of the polyglutamine expanded mutant AR. The main reason for disease attenuation is that females express lower levels of circulating androgens, such as testosterone. This theory was tested in animal models of polyglutamine expanded AR, where the reduction of testosterone levels by castration led to significant decreases in neurodegeneration in both fly and mouse models of SBMA. ${ }^{116,117}$ This principle was carried further, by the use of a known testosterone release inhibitor, leuprorelin, to significantly reduce neuropathology in mouse models. These elegant and well-controlled studies by this Japanese group also used flutamide, an AR agonist that stimulates nuclear localization of the AR, to show no therapeutic effect. ${ }^{118}$ Thus, the prevention of nuclear accumulation of the polyglutamine expanded AR has led to a therapy for SBMA that is now being tested in the clinic. Leuprorelin has already undergone human clinical phase III trials for treatment of certain types of cancer. ${ }^{119}$

This exciting prospect of the first clinical therapy for a polyglutamine disease may have two important lessons for polyglutamine disease and other neurodegenerative diseases. Firstly, that knowing the precise biological function of the protein which expresses the polyglutamine tract expansion has led to faster development of a therapy; and secondly, that the therapy was targeted to the normal biological function of the protein affected by polyglutamine expansion, and not to a biophysical property of expanded polyglutamine. The success of hormone antagonsists in SBMA could lead to a new paradigm of drug development for Huntington's disease and other polyglutamine diseases, and/or potentially lead to compounds that may be used in combination with those that inhibit polyglutamine-dependent aggregation. Despite the presence of an expanded polyglutamine tract, a more conventional target could be to inactivate the normal biological function of the protein by specific signaling inhibition to render it innocuous to the cell. This may be very challenging for Huntington's disease, because the normal huntingtin protein is essential for development, ${ }^{120}$ and may be essential for the life of any cell, as it is ubiquitously expressed in all cell types ${ }^{121}$ and is found highly conserved in all vertebrate species. ${ }^{122}$ Unlike the AR, human neurons may not be able to tolerate induced loss of normal huntingtin function.

Comparative studies between the polyglutamine diseases are relatively few in the press, but are often used to test the universality of conclusions about polyglutamine expansion in huntingtin. Some of the most detailed mouse model work in polyglutamine diseases has been accomplished by two collaborating groups of Harry Orr at the University of Minnesota and Huda Zoghbi at Baylor College on the spinocerebellar ataxia type 1 protein, ataxin- $1 .{ }^{123}$

The Spinocerebellar Ataxias (SCAs), types 1, 2, 3, 6, 7 AND 17.

Ataxia is a defect in motor coordination that typically affects gait and balance, but can additionally affect gaze and speech. ${ }^{124}$ Ataxia can be caused by a variety of factors, including metabolic dysfunction, toxicity, autoimmunity, paraneoplasm, and genetic factors. ${ }^{125}$ Over 35 loci for autosomal dominant and recessive hereditary ataxias have been identified. ${ }^{125}$ Most autosomal dominant ataxias are polyglutamine diseases, with disease causing expansions beginning in the range of 35-40; collectively, the prevalence of these diseases has been estimated at $\sim 3$ per 100,000. ${ }^{126-129}$ Clinically, these diseases primarily affect the cerebellum, brainstem and the spinal cord, but clinical features vary among the different SCAs and even within subtypes. ${ }^{129}$ Spinocerebellar Ataxias typically present as dominantly transmitted ataxia, with additional features such as dysarthria and eye movement abnormalities related to cerebellar dysfunction as well as features that vary with SCA type, such as retinopathy, optic atrophy, slow saccades, ophthalmoplegia, dementia, epilepsy, amyotrophy, spasticity, dyskinesias, parkinsonism and peripheral neuropathy. The diagnostic pathological feature that defines SCAs is olivopontocerebellar atrophy, ${ }^{130}$ except for SCA6 which manifests as pure cerebellar atrophy. Despite the common genetic mutation of an expanded polyglutamine tract in these proteins, there exist some differences in brain pathology. For example, in SCA1, 2 and 6, but not SCA3, patients have significant loss of Purkinje cells, the highly arborized cerebellar neurons with the highest number and longest input branches of any neuronal cell type. Of all the SCAs, SCA1 is perhaps the best defined in terms of molecular pathogenesis due to the extensive use of mouse genetic models. 


\section{The SCA1 Protein, AtaXin-1}

Polyglutamine-expanded ataxin-1 has several characteristics typical of polyglutamine diseases. These include genetic anticipation, age of onset varying with polyglutamine tract length (with average onset in the fourth decade), progressive neurodegeneration, toxic gain-of-function, autosomal dominance, and the presence of well defined neuronal intranuclear inclusions. ${ }^{131}$ Transgenic mouse models of SCA1 with polyglutamine expanded ataxin-1 exhibit typical ataxic phenotypes and severe loss of Purkinje cells. ${ }^{22}$ Subsequent mutant ataxin-1 transgenic models have attempted to address the role of nuclear inclusions of protein by identifying the nuclear localization signal (NLS) sequence within the protein, inactivating the signal activity with specific point-mutations and assessing the NLS-defective polyglutamine expanded ataxin-1 expressed back in the transgenic mouse model. These studies demonstrated that nuclear polyglutamine expanded ataxin-1 was necessary for generation of ataxia in the mouse, and that cytoplasmic polyglutamine expanded ataxin-1 was not toxic. ${ }^{21}$ This result contradicted work by others that indicated that polyglutamine expansion synthetically placed in any protein could lead to neurodegeneration, with noted intranuclear aggregates, and thus only expression of polyglutamine appeared to cause disease. ${ }^{132,133}$ The NLS mutant SCA1 mouse demonstrated that the polyglutamine expansion alone in any expressed protein was not sufficient to cause disease, but that nuclear localization was required. When an analysis of potential phospho-modification and signaling of ataxin-1 was carried out, a single serine adjacent to the NLS sequence was identified as being a target of phosphorylation by akt kinase, the same signaling pathway implicated in huntingtin phosphorylation. ${ }^{134}$ However, while this phosphorylation did not affect nuclear localization, transgenic mice expressing ataxin-1 with a serine to alanine mutation did not develop ataxia in a transgenic mouse, despite the presence of ataxin-1 in the nucleus. This data indicated that alone, nuclear localization of polyglutamine tracts was not sufficient for the triggering of SCA1. ${ }^{20}$ These studies on the specific akt phosphorylation site in ataxin-1 pointed to a potential therapeutic target for SCA1, by the use of akt kinase inhibitors that prevented ataxin-1 phosphorylation. ${ }^{135}$

What about the normal biological function of ataxin- 1 and its role in SCA1? Ataxin-1 is known to be a nucleic acid binding protein, binding directly to RNA. ${ }^{136}$ Ataxin-1 nuclear inclusions contain the silencing mediator of retinoid and thyroid hormone receptors, or SMRT. ${ }^{137}$ In studies where the polyglutamine tract in ataxin-1 was completely removed by mutagenesis, ataxin-1 protein still localized to nuclear inclusions, with similar characteristics to normal and polyglutamine-expanded ataxin1. ${ }^{137-139}$ When the "aggregates" of several polyglutamine disease inclusions were analyzed at the level of biophysical studies in live cells, it was found that polyglutamine-expanded ataxin-1, ataxin- 3 and huntingtin proteins were dynamic and able to move between inclusions, suggesting that the inclusions in these polyglutamine diseases were not static, aggregated protein. ${ }^{138,140}$ While polyglutamine was not required for the presence of nuclear inclusions, mRNA and active transcription were seen tied to the formation of ataxin-1 inclusions, and in response to cell stress, ataxin-1 could recruit a general mRNA export factor to these inclusions. ${ }^{139}$ Ataxin-1 is also capable of nuclear export, a function that is inhibited by polyglutamine expansion in the protein. ${ }^{139}$ These observations of ataxin-1 in transcription modulation and RNA processing suggest that the normal nuclear function of ataxin-1, in response to akt signaling, may be as a transcription modulator at the level of gene activation, RNA export, or both. Toxic specificity of mutant polyglutamineexpanded ataxin-1 in SCA1 may therefore be at the level of a precise subset of mRNAs retained in the nucleus. In terms of drug development, these elegant transgenic mouse model studies of SCA1 point to kinase inhibitors as modulators of toxicity. Thus, as with the case of the androgen receptor and SBMA, there is a potential therapy and may not be directly targeted at expanded polyglutamine. A potential overlap in function and functional pathways with ataxin-1 may be in ataxin-2, the SCA2 disease protein.

Spinocerebellar ataxia type 2, like SCA1, shows a high level of Purkinje cell loss, as well as loss in the pontine nuclei and inferior olives. Clinical features are similar to those seen in SCA1, except that tremor, slowing of saccades and hypoflexia are more common. Unlike SCA1, SCA2 pathology also extends to the substantia nigra, which may account for some patients exhibiting features of parkinsonism without ataxia.

While nuclear inclusions of ataxin-2 protein are seen in 1-2\% of cells in the brain, unlike the other polyglutamine diseases, ataxin-2 inclusions are not noted at the site of primary pathology, the Purkinje cells. ${ }^{141}$ In a SCA2 transgenic mouse model, there is no correlation of toxicity with either nuclear localization or the presence of nuclear inclusions of ataxin-2 protein. ${ }^{142}$ However, in those studies the investigators did not address the possibility that ataxin-2 may be dynamically moving between the nucleus and cytoplasm, as is seen with other polyglutamine disease proteins. Ataxin- 2 interacts with RNA binding proteins, ${ }^{143}$ and with RNA directly through an Lsm domain. ${ }^{144}$ By integrative proteomics, ataxin-2 has been implicated in RNA processing, and can co-localize with the mRNA poly A binding protein. ${ }^{145}$ Poly A binding proteins are known to dynamically shuttle between the nucleus and cytoplasm, exporting the nucleus along with RNA. ${ }^{146}$ Integrative proteomics is a relatively new method of attempting to understand the biological function of a protein using homology studies to similar proteins in other species and the pathways they participate in. This technology, by taking advantage of the completed yeast, human and other genomic sequences, also defines cellular protein-protein interactions with proteins of known function in order to infer biological function. ${ }^{147}$ The connection of both ataxin-1 and ataxin-2 to RNA suggests possible mis-processing or nuclear retention of RNA in SCA1, 2 diseases. RNA transport inhibition has precedent in neurologic disease: in Fragile X syndrome, loss of expression of FMR1, or mis-splicing leading to loss of a nuclear export signal-encoding exon, leads to lack of nuclear export of a family of mRNAs essential for normal brain development; ${ }^{148,149}$ nova RNA-associated proteins, the paraneoplastic Ri antigen RNA binding proteins, are involved in paraneoplastic opsoclonus ataxia; ${ }^{150}$ and the NTX5 RNA export factor is not expressed in some patients with X-linked mental retardation. ${ }^{151}$ As with ataxin-1, ataxin-2 toxic specificity may be dictated by the specific messenger RNAs affected by the gain-of-function in polyglutamine-expanded SCA2. 


\section{SPINOCEREbEllar AtaXia TyPes 7 AND 17}

Given that so many polyglutamine disease proteins result in Purkinje cell loss and ataxia, it may not be difficult to imagine that common mechanisms related to inter-regulatory pathways important for Purkinje cell health may be affected by multiple ataxins. Some polyglutamine-expanded proteins may act as genetic modifiers for other polyglutamine diseases. ${ }^{152}$ In SCA7, in addition to the typical Purkinje cell pathology of SCA1, marked degeneration is also noted in the retinal ganglia, the optic tract and the visual cortex (Figure 5). In the clinic, this leads to blindness in SCA7 patients in addition to progressive ataxia. ${ }^{153}$ CAG repeat lengths can exceed 200 with infantile onset in this disease. Like ataxin-1, ataxin-7 is normally nuclear. ${ }^{154}$ While SCA7 transgenic mouse models reveal a progressive accumulation of nuclear mutant ataxin-7. ${ }^{155}$ Ataxin-7's biological role is being quickly elucidated. ${ }^{156}$ It has been shown that Polyglutamine-expanded ataxin-7 can inhibit transcription of Crx-controlled genes. Crx is a transcription factor involved in the regulation of retinal genes. ${ }^{157}$ Ataxin-7 is a member of a transcription co-activator complex known as STAGA, which includes the GCN5 histone acetyl-transferase (one target of HDAC inhibitors). ${ }^{158}$ Ataxin-7's role in this complex may be to act as the molecular bridge between DNA-bound transcription factors such as Crx and GCN5 in a classic mechanism of transcription regulation by upstream DNA bound enhancers affecting RNA polymerase II mRNA transcription ${ }^{157}$ (Figure 6). Recently, ataxin-7 has been found to contain a nuclear export signal and has the ability to shuttle to and from the nucleus, an activity in common with AR, huntingtin, atrophin-1, ataxin-1 and likely ataxin-2. ${ }^{159}$ As with ataxin-1, polyglutamine expansion in

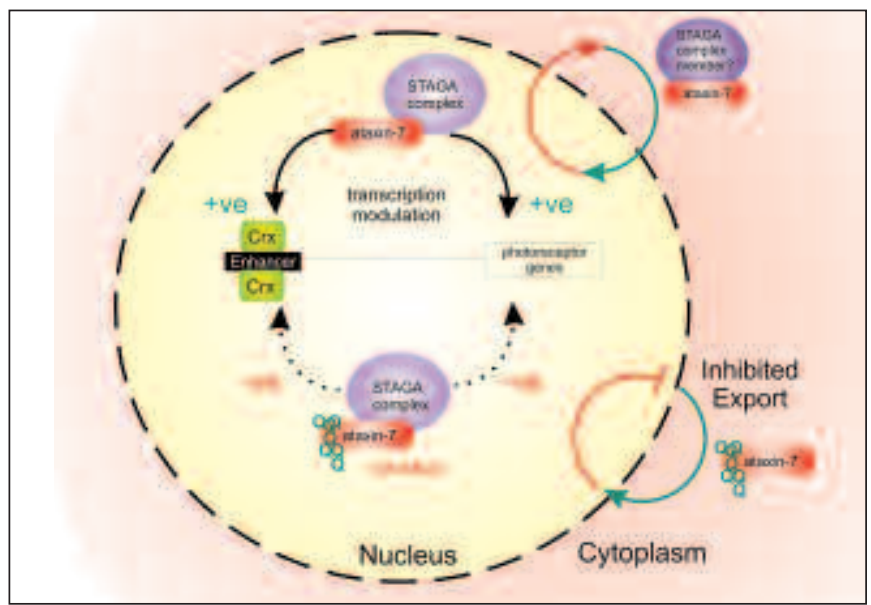

Figure 5: Regional Pathology in the Brain of Polyglutamine Diseases. Despite often ubiquitous expression in all regions of the brain and in all cell types, polyglutamine diseases are distinct in their pathology and regions of cell loss during disease. The spinocerebellar ataxias all commonly affect the cerebellum and most commonly the Purkinje cells. $H D$ primarily affects the striatum, and later the cortex, with severe mass loss by death. SCA7 displays unique retinal cell loss, visual cortex loss, and resultant blindness during disease. DRPLA affects mainly the cerebellar dentate nuclei, red nucleus in forebrain, globus pallidus and subthalmic nucleus in the basal ganglia. ataxin-7 inhibits ataxin-7 nuclear export. ${ }^{159}$ Despite the accumulation of nuclear ataxin-7 during disease progression in the SCA7 mouse model, this is not due to ubiquitin-mediated proteasome inhibition by polyglutamine-expanded ataxin-7, as aggregation in SCA7 mice inversely correlates with toxicity. ${ }^{159,160}$ Along with observations with SCA2, this suggests that in some protein contexts, aggregated polyglutamine protein may be either protective or innocuous. A similar conclusion was made for huntingtin aggregates based on experiments that monitored aggregate formation in live primary cultured neurons that showed a negative correlation with cell death. ${ }^{161}$ Consistent with these observations, compounds that have been selected to promote the aggregation of mutant huntingtin exon1 fragment, show a protective effect against toxicity. ${ }^{87}$ In addition, ataxin-7 has a short region of homology with the phospho-protein binding domain of beta-arrestins. ${ }^{162}$ Together with its shuttling activity to and from the nucleus, this domain suggests that ataxin-7 may be a beta arrestin-like molecule involved in signaling. ${ }^{163}$

Downstream of ataxin-7's role as transcription co-activator, the STAGA complex interacts with the RNA polymerase II complex at the promoter. One essential factor required for transcription of most genes by RNA polymerase II is the TATAbox binding protein, or TBP. TBP is a saddle-shaped protein that acts as a DNA-bound scaffold as part of the transcription initiation complex. TBP is highly conserved from yeast to humans, with the exception of a 38-repeat glutamine tract in human TBP. While 36 repeats of polyglutamine appear to be the disease threshold for many polyglutamine diseases, the presence of a normal tract of 38 glutamines in TBP contradicts this concept. ${ }^{164} \mathrm{TBP}$ is the disease protein affected by polyglutamine

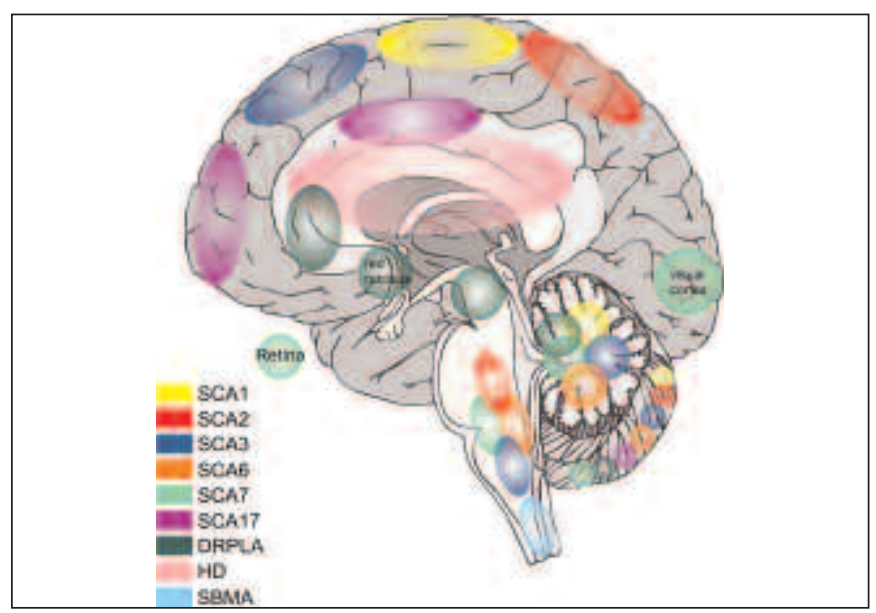

Figure 6: Model of Ataxin-7 Function and Dysfunction in SCA7. Ataxin7 is a member of the STAGA transcription co-activator complex. The amino terminus of ataxin-7 makes interactions with upstream DNAbound activators, such as Crx, and therefore modulates transcription of some retinal-specific genes. Ataxin-7 also shuttles between the nucleus and cytoplasm. Polyglutamine expansion in ataxin-7 leads to reduced nuclear export and accumulation in the nucleus. Nuclear accumulation of full-length mutant protein at concentrations above wild-type level of protein, may result in dominant inhibition by disruption of STAGA interactions or the inability to export a STAGA complex member. 
expansion in SCA17, but only when repeats are seen at greater than 50-55. ${ }^{165}$ TBP has been seen to be recruited, and likely sequestered, into nuclear inclusions of other polyglutamine disease proteins, such as ataxin-3. ${ }^{166}$ SCA17 typifies the conundrum of disease specificity in polyglutamine diseases (Figure 5). TBP function is critical to the basic mechanism of RNA polymerase II transcription, and is required in every living cell, but polyglutamine-expanded TBP specifically leads to neurologic disease, with focal dystonia, ataxia and dementia. ${ }^{167,168}$ As with other polyglutamine diseases, protein expression patterns of TBP do not dictate sites of pathology. TBP and huntingtin are just two examples of ubiquitously expressed polyglutamine disease proteins that lead to very specific cell death in neurons. The reasons for this toxic specificity are not understood, but may have to do with the normal functions of these proteins being more critical in neuronal subpopulations, or that contain neuronal sub-types that are particularly fragile and sensitive to the induced stresses triggered by polyglutamineexpanded proteins.

\section{SCA3: Machado-Joseph Disease (MJD) AND Direct Proteasome Involvement}

The protein affected in SCA3/MJD, ataxin-3, is the smallest of the polyglutamine disease proteins at 376 amino acids. ${ }^{169}$ This disease was originally described in populations with PortugueseAzorean ancestry, but is now known as the most common cause of dominant cerebellar ataxia, with a prevalent haplotype implying a genetic founder effect. ${ }^{170}$ In SCA3, Purkinje cells are affected, but to a lesser extent than SCA1, and a large amount of degeneration is seen in Clark's column, as well as vestibular and pontine nuclei. ${ }^{171}$ While inhibition of normal proteolytic turnover has been noted for some polyglutamine disease proteins, ${ }^{172,173}$ ataxin-3's role in proteasome function has been recently elucidated to be more direct. Ataxin-3 has been shown to have a deubiquitylating activity on chains of four or more ubiquitins and therefore can regulate protein degradation. ${ }^{174}$ Also, as with some other polyglutamine disease proteins, ataxin3 is seen to be proteolytically cleaved, ${ }^{175}$ and is found in intranuclear inclusions. ${ }^{113,176}$ However, live cell protein dynamic studies using green fluorescent protein fusions to ataxin-3 demonstrated that these polyglutamine dependent inclusions are not static, precipitated protein, but areas of high local concentration that are dynamic, ${ }^{177}$ as seen with ataxin-1 inclusions. ${ }^{138,139}$ Therefore, it appears that the normal function of ataxin-3 as regulator of proteasome function is being perturbed by the expanded polyglutamine tract, leading to abnormally high levels of proteins whose intracellular concentrations are normally regulated by ataxin-3. It is likely that the toxic specificity seen in SCA3 is dictated by abnormally high levels of particular proteins. An intriguing observation in the CAG tracts of ataxin-3 is that this mRNA is susceptible to frame-shifting during translation, leading to the expression of polyalanine and insolubility of ataxin-3. ${ }^{178}$ However, this mechanism has not yet been seen with other polyglutamine diseases.

\section{Dentatorubralpallidoluysian Atrophy (DRPLA), THE ATrophin-1 Protein}

Dentatorubralpallidoluysian Atrophy (DRPLA) is a very rare disease in caucasian populations, but can occur at incidences as high as 1 in 250,000 in Japanese populations. ${ }^{129}$ Dentatorubralpallidoluysian Atrophy and SCA2 are two polyglutamine diseases that show marked geographic distributions of incidence, with SCA2 as high as 1 in 500 in the Cuban population due to a genetic founder effect. ${ }^{179,180}$ Dentatorubralpallidoluysian Atrophy patients present with ataxia, as well as features similar to those found in Huntington's disease, such as dementia and choreothetosis (writhing or twitching involuntary movement), with severe juvenile-onset cases displaying myoclonus and epileptic seizures. ${ }^{181}$ One of the traits paramount to clinical diagnosis of DRPLA is pronounced mood swings and attention deficit. The polyglutamine-expanded disease protein of DRPLA is atrophin-1 with expansions of 49 or higher associated with disease. As with huntingtin and TBP, atrophin-1 is ubiquitously expressed in all tissues, and as with several polyglutamine disease proteins, is proteolytically cleaved in neuronal cells, but not in other cells. ${ }^{182}$ Atrophin-1 is differentially phosphorylated in DRPLA versus normal brains, ${ }^{183}$ suggesting a signaling role for atrophin-1. As with several other polyglutamine diseases, atrophin-1 fragments are seen to accumulate in the nucleus. ${ }^{184}$ The function of atrophin- 1 has been suggested as a transcription factor, and polyglutamine-expanded atrophin-1 can sequester the CREB binding protein (CBP) transcription factor. ${ }^{185}$ As with huntingtin, the androgen receptor, ataxin-1, and ataxin-7, atrophin-1 can shuttle to and from the nucleus. Fragmentation by proteolysis removes the nuclear export signal sequence in atrophin-1 which results in nuclear accumulation of a fragment containing a nuclear localization signal and the polyglutamine tract. ${ }^{65}$ This mechanism of gain-offunction by nuclear accumulation appears to be a common observation in several polyglutamine diseases. ${ }^{28,139,159,186}$

\section{Polyglutamine Diseases: Therapy After Disease Onset?}

Can a hypothetical polyglutamine disease therapy practically halt or reverse the neurodegenerative damage in patients and improve quality of life? The answers from sophisticated mouse genetic models are strikingly positive. In mouse genetic models in which mutant huntingtin fragment expression can be turned on or off, expression of the mutant protein results in neurodegeneration and HD-like motor dysfunction. This can be reversed as quickly as 14 days after shutting off mutant protein expression, for both huntingtin and SCA1 mouse models. ${ }^{19,187}$ In these mouse brains, restoration of the Purkinje cells or complete clearance of huntingtin aggregates was seen. ${ }^{19,188}$ The strong conclusions from these studies is that preventing expression of the polyglutamine disease protein will halt toxicity, and the brain's plasticity can lead to rapid recovery, even after severe disease has been triggered. Along with this approach to therapy, several groups are developing small inhibitory RNAs (siRNAs) as a very potent and specific molecular method of shutting off mutant protein expression. ${ }^{189}$ In the mouse model and cell biological studies, siRNAs are being seen as effective against HD, SCA3, and SCA1. ${ }^{174,190,191}$ The future of this potential route of therapy is the development of viral vectors that can introduce expression of these siRNAs into the brain or other tissues. ${ }^{190,192,193}$ The other alternative approach could be to remove the mutant proteins from their normal biological functions or mutant-gained functions by the use of small molecule inhibitors. 
Tremendous advances have been made in the field of polyglutamine diseases research, despite the relatively small size of this research field, in just over a decade. The use of researchers and clinicians with expertise in biochemistry, cell biology, as well as neurosciences, in addition to the power of mouse genetic models and small molecule screening has ensured that no stone will be left unturned in the expedient development of therapies for these tragic diseases. Current and future collaborations with pharmaceutical industry and the ongoing development of biomarkers for these diseases, as well as new technologies of viral-based therapies lay the groundwork for an exciting next few years on the road to therapy for several of the polyglutamine expansion neurodegenerative diseases.

\section{ACKNOWLEDGMENTS}

The work in this laboratory is supported by past and present grants from the Hereditary Disease Foundation, the Huntington's Disease Society of America, The Huntington's Disease Society of Canada, the High Q Foundation, the Canadian Institutes of Health Research, Genetics Institute, the Canadian Foundation for Innovation and the Ontario Innovation Trust. RT is a CIHR New Scientist Scholar.

LAR is a CIHR Investigator and Michael Smith Foundation for Research Senior Scholar.

\section{REFERENCES}

1. Schalling M, Hudson TJ, Buetow KH, Housman DE. Direct detection of novel expanded trinucleotide repeats in the human genome. Nat Genet. 1993; 4(2): 135-9.

2. Epplen C, Epplen J T. Expression of (cac)n/(gtg)n simple repetitive sequences in mRNA of human lymphocytes. Hum Genet. 1994; 93(1): 35-41.

3. La Spada AR, Wilson EM, Lubahn DB, Harding AE, Fischbeck KH. Androgen receptor gene mutations in X-linked spinal and bulbar muscular atrophy. Nature. 1991; 352(6330): 77-9.

4. A novel gene containing a trinucleotide repeat that is expanded and unstable on Huntington's disease chromosomes. The Huntington's Disease Collaborative Research Group. Cell. 1993; 72(6): 971-83.

5. Kawaguchi Y, Okamoto T, Taniwaki M, Aizawa M, Inoue M, Katayama S, et al. CAG expansions in a novel gene for MachadoJoseph disease at chromosome 14q32.1. Nat Genet. 1994; 8(3): 221-8.

6. Orr HT, Chung MY, Banfi S, Kwiatkowski TJ, Jr, Servadio A, Beaudet AL, et al. Expansion of an unstable trinucleotide CAG repeat in spinocerebellar ataxia type 1. Nat Genet. 1993; 4(3): 221-6.

7. Behn-Krappa A, Doerfler W. Enzymatic amplification of synthetic oligodeoxyribonucleotides: implications for triplet repeat expansions in the human genome. Hum Mutat. 1994; 3(1): 19-24.

8. Chong SS, McCall AE, Cota J, Subramony SH, Orr HT, Hughes MR, et al. Gametic and somatic tissue-specific heterogeneity of the expanded SCA1 CAG repeat in spinocerebellar ataxia type 1 . Nat Genet. 1995; 10(3): 344-50.

9. Cancel G, Abbas N, Stevanin G, Durr A, Chneiweiss H, Neri C, et al. Marked phenotypic heterogeneity associated with expansion of a CAG repeat sequence at the spinocerebellar ataxia 3/Machado-Joseph disease locus. Am J Hum Genet. 1995; 57(4): 809-16.

10. Trottier Y, Biancalana V, Mandel J L. Instability of CAG repeats in Huntington's disease: relation to parental transmission and age of onset. J Med Genet. 1994; 31(5): 377-82.

11. Djousse L, Knowlton B, Hayden MR, Almqvist EW, Brinkman RR, Ross CA, et al. Evidence for a modifier of onset age in Huntington disease linked to the HD gene in $4 \mathrm{p} 16$. Neurogenetics. 2004; 5(2): 109-14.
12. Li JL, Hayden MR, Almqvist EW, Brinkman RR, Durr A, Dode C, et al. A genome scan for modifiers of age at onset in Huntington disease: The HD MAPS study. Am J Hum Genet. 2003; 73(3): 682-7.

13. Ashizawa T, Dunne PW, Ward PA, Seltzer WK, Richards CS, Effects of the sex of myotonic dystrophy patients on the unstable triplet repeat in their affected offspring. Neurology. 1994; 44(1): 120-2.

14. Housman D, Gain of glutamines, gain of function? Nat Genet. 1995; 10(1): 3-4.

15. Clarke G, Collins RA, Leavitt BR, Andrews DF, Hayden MR, Lumsden CJ, et al. A one-hit model of cell death in inherited neuronal degenerations. Nature. 2000; 406(6792): 195-9.

16. Benjamin CM, Lashwood A. United Kingdom experience with presymptomatic testing of individuals at $25 \%$ risk for Huntington's disease. Clin Genet. 2000; 58(1): 41-9.

17. Langbehn DR, Brinkman RR, Falush D, Paulsen JS, Hayden MR. A new model for prediction of the age of onset and penetrance for Huntington's disease based on CAG length. Clin Genet. 2004; 65(4): 267-77.

18. Mangiarini L, Sathasivam K, Seller M, Cozens B, Harper A, Hetherington C, et al. Exon 1 of the HD gene with an expanded CAG repeat is sufficient to cause a progressive neurological phenotype in transgenic mice. Cell. 1996; 87(3): 493-506.

19. Zu T, Duvick LA, Kaytor MD, Berlinger MS, Zoghbi HY, Clark $\mathrm{HB}$, et al. Recovery from polyglutamine-induced neurodegeneration in conditional SCA1 transgenic mice. J Neurosci. 2004; 24(40): 8853-61.

20. Emamian ES, Kaytor MD, Duvick LA, Zu T, Tousey SK, Zoghbi $\mathrm{HY}$, et al. Serine 776 of ataxin-1 is critical for polyglutamineinduced disease in SCA1 transgenic mice. Neuron. 2003; 38(3): 375-87.

21. Klement IA, Skinner PJ, Kaytor MD, Yi H, Hersch SM, Clark HB, et al. Ataxin-1 nuclear localization and aggregation: role in polyglutamine-induced disease in SCA1 transgenic mice. Cell. 1998; 95(1): 41-53.

22. Burright EN, Clark HB, Servadio A, Matilla T, Feddersen RM, Yunis WS, et al. SCA1 transgenic mice: a model for neurodegeneration caused by an expanded CAG trinucleotide repeat. Cell. 1995; 82(6): 937-48.

23. Heiser V, Scherzinger E, Boeddrich A, Nordhoff E, Lurz R, Schugardt $\mathrm{N}$, et al. Inhibition of huntingtin fibrillogenesis by specific antibodies and small molecules: implications for Huntington's disease therapy. Proc Natl Acad Sci USA. 2000; 97(12): 6739-44.

24. Zhang X, Smith DL, Meriin AB, Engemann S, Russel DE, Roark M, et al. A potent small molecule inhibits polyglutamine aggregation in Huntington's disease neurons and suppresses neurodegeneration in vivo. Proc Natl Acad Sci USA. 2005; 102(3): 892-7.

25. Perutz MF, Glutamine repeats and inherited neurodegenerative diseases: molecular aspects. Curr Opin Struct Biol. 1996; 6(6): 848-58.

26. Davies SW, Turmaine M, Cozens BA, DiFiglia M, Sharp AH, Ross $\mathrm{CA}$, et al. Formation of neuronal intranuclear inclusions underlies the neurological dysfunction in mice transgenic for the HD mutation. Cell. 1997; 90(3): 537-48.

27. Wheeler VC, White JK, Gutekunst CA, Vrbanac V, Weaver M, Li X $\mathrm{J}$, et al. Long glutamine tracts cause nuclear localization of a novel form of huntingtin in medium spiny striatal neurons in HdhQ92 and HdhQ111 knock-in mice. Hum Mol Genet, 2000; 9(4): 503-13.

28. Xia J, Lee D H, Taylor J, Vandelft M, Truant R. Huntingtin contains a highly conserved nuclear export signal. Hum Mol Genet. 2003; 12(12): 1393-403.

29. Muchowski PJ. Protein misfolding, amyloid formation, and neurodegeneration: a critical role for molecular chaperones? Neuron. 2002; 35(1): 9-12.

30. Poirier MA, Jiang H, Ross CA. A structure-based analysis of huntingtin mutant polyglutamine aggregation and toxicity: evidence for a compact beta-sheet structure. Hum Mol Genet. 2005; 14(6): 765-74. 
31. Brais B, Bouchard JP, Xie YG, Rochefort DL, Chretien N, Tome FM, et al. Short GCG expansions in the PABP2 gene cause oculopharyngeal muscular dystrophy. Nat Genet. 1998; 18(2): 164-7.

32. Brais B, Rouleau GA, Bouchard JP, Fardeau M, Tome FM, Oculopharyngeal muscular dystrophy. Semin Neurol. 1999; 19(1): 59-66.

33. Utsch B, Becker $\mathrm{K}$, Brock $\mathrm{D}$, Lentze MJ, Bidlingmaier $\mathrm{F}$, Ludwig M. A novel stable polyalanine [poly(A)] expansion in the HOXA13 gene associated with hand-foot-genital syndrome: proper function of poly(A)-harbouring transcription factors depends on a critical repeat length? Hum Genet. 2002; 110(5): 488-94.

34. De Baere E, Beysen D, Oley C, Lorenz B, Cocquet J, De Sutter P, et al. FOXL2 and BPES: mutational hotspots, phenotypic variability, and revision of the genotype-phenotype correlation. Am J Hum Genet. 2003; 72(2): 478-87.

35. Kremer HP, Kremer GH. Demise of a neuronal population in Huntington's disease and the importance of hyponeuronogenesis. Clin Neurol Neurosurg. 1992; 94 Suppl: S7-8.

36. Hayden MR, Huntington's chorea. 1981, Berlin; New York: Springer-Verlag. xvii. 192

37. Vonsattel JP, Myers RH, Stevens TJ, Ferrante RJ, Bird ED, Richardson EP, Jr. Neuropathological classification of Huntington's disease. J Neuropathol Exp Neurol. 1985; 44(6): 559-77.

38. Sapp E, Schwarz C, Chase K, Bhide PG, Young AB, Penney J, et al. Huntingtin localization in brains of normal and Huntington's disease patients. Ann Neurol. 1997; 42(4): 604-12.

39. Raymond LA G, A. Huntington's disease: Targeting the triad. Canadian Journal of Diagnosis. 2005; April: 82-7.

40. Maruyama H, Kawakami H, Nakamura S. Reevaluation of the exact CAG repeat length in hereditary cerebellar ataxias using highly denaturing conditions and long PCR. Hum Genet. 1996; 97(5): 591-5.

41. Norremolle A, Riess O, Epplen JT, Fenger K, Hasholt L, Sorensen SA. Trinucleotide repeat elongation in the Huntingtin gene in Huntington disease patients from 71 Danish families. Hum Mol Genet. 1993; 2(9): 1475-6.

42. Trottier Y, Lutz Y, Stevanin G, Imbert G, Devys D, Cancel G, et al. Polyglutamine expansion as a pathological epitope in Huntington's disease and four dominant cerebellar ataxias. Nature. 1995; 378(6555): 403-6.

43. Wanker EE, Rovira C, Scherzinger E, Hasenbank R, Walter S, Tait D, et al. HIP-I: a huntingtin interacting protein isolated by the yeast two-hybrid system. Hum Mol Genet. 1997; 6(3): 48795

44. Li XJ, Li SH, Sharp AH, Nucifora FC, Jr., Schilling G, Lanahan A, et al. A huntingtin-associated protein enriched in brain with implications for pathology. Nature. 1995; 378(6555): 398-402.

45. Faber PW, Barnes GT, Srinidhi J, Chen J, Gusella JF, MacDonald ME. Huntingtin interacts with a family of WW domain proteins. Hum Mol Genet. 1998; 7(9): 1463-74

46. Passani LA, Bedford MT, Faber PW, McGinnis KM, Sharp AH, Gusella JF, et al. Huntingtin's WW domain partners in Huntington's disease post-mortem brain fulfill genetic criteria for direct involvement in Huntington's disease pathogenesis. Hum Mol Genet. 2000; 9(14): 2175-82.

47. Block-Galarza J, Chase KO, Sapp E, Vaughn KT, Vallee RB, DiFiglia M, et al. Fast transport and retrograde movement of huntingtin and HAP 1 in axons. Neuroreport. 1997; 8(9-10): 2247-51.

48. McPherson PS. The endocytic machinery at an interface with the actin cytoskeleton: a dynamic, hip intersection. Trends Cell Biol. 2002; 12(7): 312-5.

49. Ferrier V. Hip, hip, hippi! Nat Cell Biol. 2002; 4(2): E30.

50. Lee SJ, Choi JY, Sung YM, Park H, Rhim H, Kang S. E3 ligase activity of RING finger proteins that interact with Hip-2, a human ubiquitin-conjugating enzyme. FEBS Lett. 2001; 503(1): 61-4.

51. Holbert S, Denghien I, Kiechle T, Rosenblatt A, Wellington C, Hayden MR, et al. The Gln-Ala repeat transcriptional activator CA150 interacts with huntingtin: neuropathologic and genetic evidence for a role in Huntington's disease pathogenesis. Proc Natl Acad Sci U S A. 2001; 98(4): 1811-6.
52. McMahon HT, Mills IG. COP and clathrin-coated vesicle budding: different pathways, common approaches. Curr Opin Cell Biol. 2004; 16(4): 379-91.

53. Wu LG. Kinetic regulation of vesicle endocytosis at synapses. Trends Neurosci. 2004; 27(9): 548-54.

54. Rohrbough J, Broadie K. Lipid regulation of the synaptic vesicle cycle. Nat Rev Neurosci. 2005; 6(2): 139-50.

55. Phelps MA, Foraker AB, Swaan PW. Cytoskeletal motors and cargo in membrane trafficking: opportunities for high specificity in drug intervention. Drug Discov Today. 2003; 8(11): 494-502.

56. Dell KR. Dynactin polices two-way organelle traffic. J Cell Biol. 2003; 160(3): 291-3.

57. Pal A, Severin F, Lommer B, Shevchenko A, Zerial M. HuntingtinHAP40 complex is a novel Rab5 effector that regulates early endosome motility and is up-regulated in Huntington's disease. $\mathrm{J}$ Cell Biol. 2006; 172(4): 605-18.

58. DiFiglia M, Sapp E, Chase K, Schwarz C, Meloni A, Young C, et al. Huntingtin is a cytoplasmic protein associated with vesicles in human and rat brain neurons. Neuron. 1995; 14(5): 1075-81.

59. De Rooij KE, Dorsman JC, Smoor MA, Den Dunnen JT, Van Ommen GJ. Subcellular localization of the Huntington's disease gene product in cell lines by immunofluorescence and biochemical subcellular fractionation. Hum Mol Genet. 1996; 5(8): 1093-9.

60. Zuccato C, Tartari M, Crotti A, Goffredo D, Valenza M, Conti L, et al. Huntingtin interacts with REST/NRSF to modulate the transcription of NRSE-controlled neuronal genes. Nat Genet. 2003; 35(1): 76-83.

61. Cattaneo E, Rigamonti D, Zuccato C, The enigma of Huntington's disease. Sci Am. 2002; 287(6): 92-7.

62. Zuccato C, Ciammola A, Rigamonti D, Leavitt BR, Goffredo D, Conti L, et al. Loss of huntingtin-mediated BDNF gene transcription in Huntington's disease. Science. 2001; 293(5529): 493-8.

63. Perez-Navarro E, Canudas AM, Akerund P, Alberch J, Arenas E. Brain-derived neurotrophic factor, neurotrophin-3, and neurotrophin- $4 / 5$ prevent the death of striatal projection neurons in a rodent model of Huntington's disease. J Neurochem. 2000; 75(5): 2190-9.

64. Bemelmans AP, Horellou P, Pradier L, Brunet I, Colin P, Mallet J. Brain-derived neurotrophic factor-mediated protection of striatal neurons in an excitotoxic rat model of Huntington's disease, as demonstrated by adenoviral gene transfer. Hum Gene Ther. 1999; 10(18): 2987-97.

65. Nucifora FC, Jr, Ellerby LM, Wellington CL, Wood JD, Herring WJ, Sawa A, et al. Nuclear localization of a non-caspase truncation product of atrophin-1, with an expanded polyglutamine repeat, increases cellular toxicity. J Biol Chem. 2003; 278(15): 1304755 .

66. Steffan JS, Kazantsev A, Spasic-Boskovic O, Greenwald M, Zhu Y $\mathrm{Z}$, Gohler H, et al. The Huntington's disease protein interacts with p53 and CREB-binding protein and represses transcription. Proc Natl Acad Sci USA. 2000; 97(12): 6763-8.

67. Gauthier LR, Charrin BC, Borrell-Pages M, Dompierre JP, Rangone H, Cordelieres FP, et al. Huntingtin controls neurotrophic support and survival of neurons by enhancing BDNF vesicular transport along microtubules. Cell. 2004; 118(1): 127-38

68. Zeitlin S, Liu JP, Chapman DL, Papaioannou VE, Efstratiadis A. Increased apoptosis and early embryonic lethality in mice nullizygous for the Huntington's disease gene homologue. Nat Genet. 1995; 11(2): 155-63.

69. Rosen A. Huntingtin: new marker along the road to death? Nat Genet. 1996; 13(4): 380-2.

70. Wellington CL, Ellerby LM, Hackam AS, Margolis RL, Trifiro MA, Singaraja R, et al. Caspase cleavage of gene products associated with triplet expansion disorders generates truncated fragments containing the polyglutamine tract. J Biol Chem. 1998; 273(15): 9158-67.

71. Tobin AJ, Signer ER. Huntington's disease: the challenge for cell biologists. Trends Cell Biol. 2000; 10(12): 531-6. 
72. Kells AP, Fong DM, Dragunow M, During MJ, Young D, Connor B. AAV-mediated gene delivery of BDNF or GDNF is neuroprotective in a model of Huntington disease. Mol Ther. 2004; 9(5): 682-8.

73. Hillson JL, Furst DE. Rofecoxib. Expert Opin Pharmacother. 2000; 1(5): 1053-66.

74. Matsumoto AK, Cavanaugh PF Jr. Etoricoxib. Drugs Today (Barc). 2004; 40(5): 395-414.

75. Liu S, Jiang S. High throughput screening and characterization of HIV-1 entry inhibitors targeting gp41: theories and techniques. Curr Pharm Des. 2004; 10(15): 1827-43.

76. Flynn DL, Abood NA, Holwerda BC. Recent advances in antiviral research: identification of inhibitors of the herpesvirus proteases. Curr Opin Chem Biol. 1997; 1(2): 190-6.

77. Wesche H, Xiao SH, Young SW. High throughput screening for protein kinase inhibitors. Comb Chem High Throughput Screen. 2005; 8(2): 181-95.

78. Kazantsev A, Walker HA, Slepko N, Bear JE, Preisinger E, Steffan JS, et al. A bivalent Huntingtin binding peptide suppresses polyglutamine aggregation and pathogenesis in Drosophila. Nat Genet. 2002; 30(4): 367-76.

79. Heiser V, Engemann S, Brocker W, Dunkel I, Boeddrich A, Waelter $\mathrm{S}$, et al. Identification of benzothiazoles as potential polyglutamine aggregation inhibitors of Huntington's disease by using an automated filter retardation assay. Proc Natl Acad Sci USA. 2002; 99 Suppl 4: S16400-6.

80. Pollitt SK, Pallos J, Shao J, Desai UA, Ma AA, Thompson LM, et al. A rapid cellular FRET assay of polyglutamine aggregation identifies a novel inhibitor. Neuron. 2003; 40(4): 685-94.

81. Khoshnan A, Ko J, Patterson PH. Effects of intracellular expression of anti-huntingtin antibodies of various specificities on mutant huntingtin aggregation and toxicity. Proc Natl Acad Sci USA. 2002; 99(2): 1002-7.

82. Qin ZH, Wang Y, Sapp E, Cuiffo B, Wanker E, Hayden MR, et al. Huntingtin bodies sequester vesicle-associated proteins by a polyproline-dependent interaction. J Neurosci. 2004; 24(1): 26981.

83. Wang J, Gines S, MacDonald ME, Gusella JF. Reversal of a fulllength mutant huntingtin neuronal cell phenotype by chemical inhibitors of polyglutamine-mediated aggregation. BMC Neurosci. 2005; 6(1): 1 .

84. Hoshino M, Tagawa K, Okuda T, Murata M, Oyanagi K, Arai N, et al. Histone deacetylase activity is retained in primary neurons expressing mutant huntingtin protein. J Neurochem. 2003; 87(1): 257-67.

85. Steffan JS, Bodai L, Pallos J, Poelman M, McCampbell A, Apostol BL, et al. Histone deacetylase inhibitors arrest polyglutamine-dependent neurodegeneration in Drosophila. Nature. 2001; 413(6857): 739-43.

86. Ferrante RJ, Kubilus JK, Lee J, Ryu H, Beesen A, Zucker B, et al. Histone deacetylase inhibition by sodium butyrate chemotherapy ameliorates the neurodegenerative phenotype in Huntington's disease mice. J Neurosci. 2003; 23(28): 9418-27.

87. Bodner RA, Outeiro TF, Altmann S, Maxwell MM, Cho SH, Hyman BT, et al. Pharmacologinal promotion of inclusion formation: a therapeutic approach for Huntington's and Parkinson's diseases. Proc Natl Acad Sci USA. 2006; 103(1): 4246-51.

88. Stockwell BR. Chemical genetic screening approaches to neurobiology. Neuron. 2002; 36(4): 559-62.

89. Jelkmann W, Molecular biology of erythropoietin. Intern Med. 2004; 43(8): 649-59.

90. Barnes PJ, Hansel TT. Prospects for new drugs for chronic obstructive pulmonary disease. Lancet. 2004; 364(9438): 985-96.

91. Alarcon de la Lastra C, Sanchez-Fidalgo S, Villegas I, Motilva V. New pharmacological perspectives and therapeutic potential of PPAR-gamma agonists. Curr Pharm Des. 2004; 10(28): 3505-24.

92. Lou YR, Qiao S, Talonpoika R, Syvala H, Tuohimaa P. The role of Vitamin D3 metabolism in prostate cancer. J Steroid Biochem Mol Biol. 2004; 92(4): 317-25.

93. Platet N, Cathiard AM, Gleizes M, Garcia M. Estrogens and their receptors in breast cancer progression: a dual role in cancer proliferation and invasion. Crit Rev Oncol Hematol. 2004; 51(1): $55-67$.
94. Humbert S, Bryson EA, Cordelieres FP, Connors NC, Datta SR, Finkbeiner S, et al. The IGF-1/Akt pathway is neuroprotective in Huntington's disease and involves Huntingtin phosphorylation by Akt. Dev Cell. 2002; 2(6): 831-7.

95. Gines S, Ivanova E, Seong IS, Saura CA, MacDonald ME. Enhanced Akt signaling is an early pro-survival response that reflects $\mathrm{N}$-methyl-D-aspartate receptor activation in Huntington's disease knock-in striatal cells. J Biol Chem. 2003; 278(50): 50514-22.

96. Kumar U, Asotra K, Patel SC, Patel YC. Expression of NMDA receptor-1 (NR1) and huntingtin in striatal neurons which colocalize somatostatin, neuropeptide $\mathrm{Y}$, and NADPH diaphorase: a double-label histochemical and immunohistochemical study. Exp Neurol. 1997; 145(2 Pt 1): 412-24.

97. Chen N, Luo T, Wellington C, Metzler M, McCutcheon K, Hayden MR, et al. Subtype-specific enhancement of NMDA receptor currents by mutant huntingtin. J Neurochem. 1999; 72(5): 18908.

98. Zeron MM, Chen N, Moshaver A, Lee AT, Wellington CL, Hayden MR, et al. Mutant huntingtin enhances excitotoxic cell death. Mol Cell Neurosci. 2001; 17(1): 41-53.

99. Anborgh PH, Godin C, Pampillo M, Dhami GK, Dale LB, Cregan SP, et al. Inhibition of metabotropic glutamate receptor signaling by the huntingtin-binding protein optineurin. J Biol Chem. 2005; 280(41): 34840-8.

100.Takano H, Gusella JF. The predominantly HEAT-like motif structure of huntingtin and its association and coincident nuclear entry with dorsal, an NF-kB/Rel/dorsal family transcription factor. BMC Neurosci. 2002; 3(1): 15 .

101.Khoshnan A, Ko J, Watkin EE, Paige LA, Reinhart PH, Patterson PH. Activation of the IkappaB kinase complex and nuclear factor-kappaB contributes to mutant huntingtin neurotoxicity. J Neurosci. 2004; 24(37): 7999-8008.

102. Garcia M, Charvin D, Caboche J. Expanded huntingtin activates the c-Jun terminal kinase/c-Jun pathway prior to aggregate formation in striatal neurons in culture. Neuroscience. 2004; 127(4): 85970

103.Bezprozvanny I, Hayden MR. Deranged neuronal calcium signaling and Huntington disease. Biochem Biophys Res Commun. 2004; 322(4): 1310-7.

104.Tang TS, Slow E, Lupu V, Stavrovskaya IG, Sugimori M, Llinas R, et al. Disturbed $\mathrm{Ca} 2+$ signaling and apoptosis of medium spiny neurons in Huntington's disease. Proc Natl Acad Sci USA. 2005; 102(7): 2602-7.

105.Panov AV, Lund S, Greenamyre JT. Ca2+-induced permeability transition in human lymphoblastoid cell mitochondria from normal and Huntington's disease individuals. Mol Cell Biochem. 2005; 269(1-2): 143-52.

106.Zhuchenko O, Bailey J, Bonnen P, Ashizawa T, Stockton DW, Amos $\mathrm{C}$, et al. Autosomal dominant cerebellar ataxia (SCA6) associated with small polyglutamine expansions in the alpha 1A-voltagedependent calcium channel. Nat Genet. 1997; 15(1): 62-9.

107. Matsuyama Z, Yanagisawa NK, Aoki Y, Black JL 3rd, Lennon VA, Mori Y, et al. Polyglutamine repeats of spinocerebellar ataxia 6 impair the cell-death-preventing effect of $\mathrm{CaV} 2.1 \mathrm{Ca} 2+$ channel-loss-of-function cellular model of SCA6. Neurobiol Dis. 2004; 17(2): 198-204

108.Brinkmann AO, Trapman J. Androgen receptor mutants that affect normal growth and development. Cancer Surv. 1992; 14: 95-111.

109.Diamond M, Watson LA. Androgen insensitivity syndrome and Klinefelter's syndrome: sex and gender considerations. Child Adolesc Psychiatr Clin N Am. 2004; 13(3): 623-40, viii.

110.Lingappa VR, Blobel G. Early events in the biosynthesis of secretory and membrane proteins: the signal hypothesis. Recent Prog Horm Res. 1980; 36: 451-75.

111. Saporita AJ, Zhang Q, Navai N, Dincer Z, Hahn J, Cai X, et al. Identification and characterization of a ligand-regulated nuclear export signal in androgen receptor. J Biol Chem. 2003; 278(43): 41998-2005.

112. Adachi H, Katsuno M, Minamiyama M, Waza M, Sang C, Nakagomi $Y$, et al. Widespread nuclear and cytoplasmic accumulation of mutant androgen receptor in SBMA patients. Brain. 2005; 128(Pt 3): 659-70. 
113.Paulson HL, Perez MK, Trottier Y, Trojanowski JQ, Subramony SH, Das SS, et al. Intranuclear inclusions of expanded polyglutamine protein in spinocerebellar ataxia type 3. Neuron. 1997; 19(2): 333-44.

114. Suhr ST, Senut MC, Whitelegge JP, Faull KF, Cuizon DB, Gage FH. Identities of sequestered proteins in aggregates from cells with induced polyglutamine expression. J Cell Biol. 2001; 153(2): 283-94.

115. Stenoien DL, Cummings CJ, Adams HP, Mancini MG, Patel K, DeMartino GN, et al. Polyglutamine-expanded androgen receptors form aggregates that sequester heat shock proteins, proteasome components and SRC-1, and are suppressed by the HDJ-2 chaperone. Hum Mol Genet. 1999; 8(5): 731-41.

116. Katsuno M, Adachi H, Kume A, Li M, Nakagomi Y, Niwa H, et al. Testosterone reduction prevents phenotypic expression in a transgenic mouse model of spinal and bulbar muscular atrophy. Neuron. 2002; 35(5): 843-54.

117. Takeyama K, Ito S, Yamamoto A, Tanimoto H, Furutani T, Kanuka $\mathrm{H}$, et al. Androgen-dependent neurodegeneration by polyglutamine-expanded human androgen receptor in Drosophila. Neuron. 2002; 35(5): 855-64.

118. Katsuno M, Adachi H, Tanaka F, Sobue G. Spinal and bulbar muscular atrophy: ligand-dependent pathogenesis and therapeutic perspectives. J Mol Med. 2004; 82(5): 298-307.

119. Randomized trial of leuprorelin and flutamide in male patients with hepatocellular carcinoma treated with tamoxifen. Hepatology. 2004; 40(6): 1361-9.

120. White JK, Auerbach W, Duyao MP, Vonsattel JP, Gusella JF, Joyner $\mathrm{AL}$, et al. Huntingtin is required for neurogenesis and is not impaired by the Huntington's disease CAG expansion. Nat Genet. 1997; 17(4): 404-10.

121.Landwehrmeyer GB, McNeil SM, Dure LS 4th, Ge P, Aizawa H, Huang Q, et al. Huntington's disease gene: regional and cellular expression in brain of normal and affected individuals. Ann Neurol. 1995; 37(2): 218-30.

122. Matsuyama N, Hadano S, Onoe K, Osuga H, Showguchi-Miyata J, Gondo $\mathrm{Y}$, et al. Identification and characterization of the miniature pig Huntington's disease gene homolog: evidence for conservation and polymorphism in the $\mathrm{CAG}$ triplet repeat. Genomics. 2000; 69(1): 72-85.

123. Orr HT, Zoghbi HY. SCA1 molecular genetics: a history of a 13 year collaboration against glutamines. Hum Mol Genet. 2001; 10(20): 2307-11.

124. Di Donato S. The complex clinical and genetic classification of inherited ataxias. I. Dominant ataxias. Ital J Neurol Sci, 1998; 19(6): 335-43.

125.Taroni F, Di Donato S. Pathways to motor incoordination: the inherited ataxias. Nat Rev Neurosci. 2004; 5(8): 641-55.

126.Silveira I, Lopes-Cendes I, Kish S, Maciel P, Gaspar C, Coutinho P, et al. Frequency of spinocerebellar ataxia type 1, dentatorubropallidoluysian atrophy, and Machado-Joseph disease mutations in a large group of spinocerebellar ataxia patients. Neurology. 1996; 46(1): 214-8

127.van de Warrenburg BP, Sinke RJ, Verschuuren-Bemelmans CC, Scheffer H, Brunt ER, Ippel PF, et al. Spinocerebellar ataxias in the Netherlands: prevalence and age at onset variance analysis. Neurology. 2002; 58(5): 702-8

128. Albin RL. Dominant ataxias and Friedreich ataxia: an update. Curr Opin Neurol. 2003; 16(4): 507-14.

129. Schols L, Bauer P, Schmidt T, Schulte T, Riess O. Autosomal dominant cerebellar ataxias: clinical features, genetics, and pathogenesis. Lancet Neurol. 2004; 3(5): 291-304.

130.Zoghbi HY, Orr HT, Glutamine repeats and neurodegeneration. Annu Rev Neurosci. 2000; 23: 217-47.

131.Zoghbi HY, Orr HT. Spinocerebellar ataxia type 1. Semin Cell Biol. 1995; 6(1): 29-35.

132. Ordway JM, Tallaksen-Greene S, Gutekunst CA, Bernstein EM, Cearley JA, Wiener HW, et al. Ectopically expressed CAG repeats cause intranuclear inclusions and a progressive late onset neurological phenotype in the mouse. Cell. 1997; 91(6): 753-63.

133. Ordway JM, Cearley JA, Detloff PJ. CAG-polyglutamine-repeat mutations: independence from gene context. Philos Trans R Soc Lond B Biol Sci. 1999; 354(1386): 1083-8.
134. Chen HK, Fernandez-Funez P, Acevedo SF, Lam YC, Kaytor MD, Fernandez MH, et al. Interaction of Akt-phosphorylated ataxin-1 with 14-3-3 mediates neurodegeneration in spinocerebellar ataxia type 1. Cell. 2003; 113(4): 457-68.

135. Kaytor MD, Byam CE, Tousey SK, Stevens SD, Zoghbi HY, Orr HT. A cell-based screen for modulators of ataxin-1 phosphorylation. Hum Mol Genet. 2005; 14(8): 1095-105.

136. Yue S, Serra HG, Zoghbi HY, Orr HT. The spinocerebellar ataxia type 1 protein, ataxin-1, has RNA-binding activity that is inversely affected by the length of its polyglutamine tract. Hum Mol Genet. 2001; 10(1): 25-30.

137. Tsai CC, Kao HY, Mitzutani A, Banayo E, Rajan H, McKeown M, et al. Ataxin 1, a SCA1 neurodegenerative disorder protein, is functionally linked to the silencing mediator of retinoid and thyroid hormone receptors. Proc Natl Acad Sci USA. 2004; 101(12): 4047-52.

138. Stenoien DL, Mielke M, Mancini MA. Intranuclear ataxin1 inclusions contain both fast- and slow-exchanging components. Nat Cell Biol. 2002; 4(10): 806-10.

139. Irwin S, Vandelft M, Pinchev D, Howell JL, Graczyk J, Orr HT, et al. RNA association and nucleocytoplasmic shuttling by ataxin- 1 . J Cell Sci. 2005; 118(Pt 1): 233-42.

140.Kim S, Nollen EA, Kitagawa K, Bindokas VP, Morimoto RI. Polyglutamine protein aggregates are dynamic. Nat Cell Biol. 2002; 4(10): 826-31.

141.Koyano S, Uchihara T, Fujigasaki H, Nakamura A, Yagishita S, Iwabuchi K. Neuronal intranuclear inclusions in spinocerebellar ataxia type 2: triple-labeling immunofluorescent study. Neurosci Lett. 1999; 273(2): 117-20.

142.Huynh DP, Figueroa K, Hoang N, Pulst SM. Nuclear localization or inclusion body formation of ataxin-2 are not necessary for SCA2 pathogenesis in mouse or human. Nat Genet. 2000; 26(1): 44-50.

143. Shibata H, Huynh DP, Pulst SM. A novel protein with RNA-binding motifs interacts with ataxin-2. Hum Mol Genet. 2000; 9(9): 130313.

144.Albrecht M, Golatta M, Wullner U, Lengauer T. Structural and functional analysis of ataxin-2 and ataxin-3. Eur $\mathrm{J}$ Biochem. 2004; 271(15): 3155-70.

145.Ralser M, Albrecht M, Nonhoff U, Lengauer T, Lehrach H, Krobitsch S. An integrative approach to gain insights into the cellular function of human ataxin-2. J Mol Biol. 2005; 346(1): 203-14.

146.Pinol-Roma S, Dreyfuss G. Shuttling of pre-mRNA binding proteins between nucleus and cytoplasm. Nature. 1992; 355(6362): 730-2.

147.Jorgensen P, Breitkreutz BJ, Breitkreutz K, Stark C, Liu G, Cook M, et al. Harvesting the genome's bounty: integrative genomics. Cold Spring Harb Symp Quant Biol. 2003; 68: 431-43.

148.Eberhart DE, Malter HE, Feng Y, Warren ST. The fragile X mental retardation protein is a ribonucleoprotein containing both nuclear localization and nuclear export signals. Hum Mol Genet. 1996; 5(8): 1083-91.

149. Brown V, Jin P, Ceman S, Darnell JC, O'Donnell WT, Tenenbaum S A, et al. Microarray identification of FMRP-associated brain mRNAs and altered mRNA translational profiles in fragile $\mathrm{X}$ syndrome. Cell. 2001; 107(4): 477-87.

150.Ule J, Jensen KB, Ruggiu M, Mele A, Ule A, Darnell RB. CLIP identifies Nova-regulated RNA networks in the brain. Science. 2003; 302(5648): 1212-5

151.Jun L, Frints S, Duhamel H, Herold A, Abad-Rodrigues J, Dotti C, et al. NXF5, a novel member of the nuclear RNA export factor family, is lost in a male patient with a syndromic form of mental retardation. Curr Biol. 2001; 11(18): 1381-91.

152. Hayes S, Turecki G, Brisebois K, Lopes-Cendes I, Gaspar C, Riess $\mathrm{O}$, et al. CAG repeat length in RAI1 is associated with age at onset variability in spinocerebellar ataxia type 2 (SCA2). Hum Mol Genet. 2000; 9(12): 1753-8.

153.Gouw LG, Digre KB, Harris CP, Haines JH, Ptacek LJ. Autosomal dominant cerebellar ataxia with retinal degeneration: clinical, neuropathologic, and genetic analysis of a large kindred. Neurology. 1994; 44(8): 1441-7.

154.Kaytor MD, Duvick LA, Skinner PJ, Koob MD, Ranum LP, Orr HT. Nuclear localization of the spinocerebellar ataxia type 7 protein, ataxin-7. Hum Mol Genet. 1999; 8(9): 1657-64. 
155. Yoo SY, Pennesi ME, Weeber EJ, Xu B, Atkinson R, Chen S, et al. SCA7 knockin mice model human SCA7 and reveal gradual accumulation of mutant ataxin-7 in neurons and abnormalities in short-term plasticity. Neuron. 2003; 37(3): 383-401.

156. Grote SK, La Spada AR. Insights into the molecular basis of polyglutamine neurodegeneration from studies of a spinocerebellar ataxia type 7 mouse model. Cytogenet Genome Res. 2003; 100(1-4): 164-74.

157.Chen S, Peng GH, Wang X, Smith AC, Grote SK, Sopher BL, et al. Interference of Crx-dependent transcription by ataxin-7 involves interaction between the glutamine regions and requires the ataxin-7 carboxy-terminal region for nuclear localization. Hum Mol Genet. 2004; 13(1): 53-67.

158. Helmlinger D, Hardy S, Sasorith S, Klein F, Robert F, Weber C, et al. Ataxin-7 is a subunit of GCN5 histone acetyltransferasecontaining complexes. Hum Mol Genet. 2004; 13(12): 1257-65.

159. Taylor J, Grote SK, Xia J, Vandelft M, Graczyk J, Ellerby LM, et al. Ataxin-7 can export from the nucleus via a conserved exportindependent signal. J Biol Chem. 2006; 281(5): 2730-9.

160.Bowman AB, Yoo SY, Dantuma NP, Zoghbi HY. Neuronal dysfunction in a polyglutamine disease model occurs in the absence of ubiquitin-proteasome system impairment and inversely correlates with the degree of nuclear inclusion formation. Hum Mol Genet. 2005; 14(5): 679-91.

161.Arrasate M, Mitra S, Schweitzer ES, Segal MR, Finkbeiner S. Inclusion body formation reduces levels of mutant huntingtin and the risk of neuronal death. Nature. 2004; 431(7010): 805-10.

162.Mushegian AR, Vishnivetskiy SA, Gurevich VV. Conserved phosphoprotein interaction motif is functionally interchangeable between ataxin-7 and arrestins. Biochemistry. 2000; 39(23): 6809-13.

163.Lefkowitz RJ, Shenoy SK. Transduction of receptor signals by betaarrestins. Science, 2005; 308(5721): 512-7.

164.La Spada AR, Paulson HL, Fischbeck KH. Trinucleotide repeat expansion in neurological disease. Ann Neurol. 1994; 36(6): 81422.

165.Bruni AC, Takahashi-Fujigasaki J, Maltecca F, Foncin JF, Servadio A, Casari G, et al. Behavioral disorder, dementia, ataxia, and rigidity in a large family with TATA box-binding protein mutation. Arch Neurol. 2004; 61(8): 1314-20.

166.Perez MK, Paulson HL, Pendse SJ, Saionz SJ, Bonini NM, Pittman RN. Recruitment and the role of nuclear localization in polyglutamine-mediated aggregation. J Cell Biol. 1998; 143(6): 1457-70.

167.Gunther P, Storch A, Schwarz J, Sabri O, Steinbach P, Wagner A, et al. Basal ganglia involvement of a patient with SCA 17--a new form of autosomal dominant spinocerebellar ataxia. J Neurol. 2004; 251(7): 896-7.

168.Hagenah JM, Zuhlke C, Hellenbroich Y, Heide W, Klein C. Focal dystonia as a presenting sign of spinocerebellar ataxia 17. Mov Disord. 2004; 19(2): 217-20.

169.Ichikawa Y, Goto J, Hattori M, Toyoda A, Ishii K, Jeong SY, et al. The genomic structure and expression of MJD, the MachadoJoseph disease gene. J Hum Genet. 2001; 46(7): 413-22.

170.Gaspar C, Lopes-Cendes I, Hayes S, Goto J, Arvidsson K, Dias A, et al. Ancestral origins of the Machado-Joseph disease mutation: a worldwide haplotype study. Am J Hum Genet. 2001; 68(2): 523-8.

171.Durr A, Stevanin G, Cancel G, Duyckaerts C, Abbas N, Didierjean $\mathrm{O}$, et al. Spinocerebellar ataxia 3 and Machado-Joseph disease: clinical, molecular, and neuropathological features. Ann Neurol. 1996; 39(4): 490-9.

172.Bennett EJ, Bence NF, Jayakumar R, Kopito RR. Global impairment of the ubiquitin-proteasome system by nuclear or cytoplasmic protein aggregates precedes inclusion body formation. Mol Cell. 2005; 17(3): 351-65.

173.Park Y, Hong S, Kim S J, Kang S. Proteasome function is inhibited by polyglutamine-expanded ataxin-1, the SCA1 gene product. Mol Cells. 2005; 19(1): 23-30.

174.Burnett BG, Pittman RN. The polyglutamine neurodegenerative protein ataxin 3 regulates aggresome formation. Proc Natl Acad Sci USA. 2005; 102(12): 4330-5.
175.Goti D, Katzen SM, Mez J, Kurtis N, Kiluk J, Ben-Haiem L, et al. A mutant ataxin-3 putative-cleavage fragment in brains of Machado-Joseph disease patients and transgenic mice is cytotoxic above a critical concentration. J Neurosci. 2004; 24(45): 10266-79.

176.Schmidt T, Landwehrmeyer GB, Schmitt I, Trottier Y, Auburger G, Laccone $\mathrm{F}$, et al. An isoform of ataxin-3 accumulates in the nucleus of neuronal cells in affected brain regions of SCA3 patients. Brain Pathol. 1998; 8(4): 669-79.

177. Chai Y, Shao J, Miller VM, Williams A, Paulson HL. Live-cell imaging reveals divergent intracellular dynamics of polyglutamine disease proteins and supports a sequestration model of pathogenesis. Proc Natl Acad Sci USA. 2002; 99(14): 9310-5.

178.Gaspar C, Jannatipour M, Dion P, Laganiere J, Sequeiros J, Brais B, et al. CAG tract of MJD-1 may be prone to frameshifts causing polyalanine accumulation. Hum Mol Genet. 2000; 9(13): 195766.

179. Silveira I, Manaia A, Melki J, Magarino C, Lunkes A, Hernandez A, et al. Machado-Joseph disease is genetically different from Holguin dominant ataxia (SCA2). Genomics. 1993; 17(3): 556-9.

180. Velazquez-Perez L, Garcia R, Santos FN, Paneque HM, Medina HE, Hechavarria PR. [Hereditary ataxias in Cuba. Historical, epidemiological, clinical, electrophysiological and quantitative neurological features]. Rev Neurol, 2001; 32(1): 71-6.

181. Komure O, Sano A, Nishino N, Yamauchi N, Ueno S, Kondoh K, et al. DNA analysis in hereditary dentatorubral-pallidoluysian atrophy: correlation between CAG repeat length and phenotypic variation and the molecular basis of anticipation. Neurology. 1995; 45(1): 143-9.

182. Yazawa I, Hazeki N, Kanazawa I. Different complex formations of dentatorubral-pallidoluysian atrophy (DRPLA) protein in human and rat neurons. Biochem Biophys Res Commun. 1998; 253(2): 209-13.

183. Yazawa I. Aberrant phosphorylation of dentatorubral-pallidoluysian atrophy (DRPLA) protein complex in brain tissue. Biochem J.2000; 351 Pt 3: 587-93.

184. Schilling G, Wood JD, Duan K, Slunt HH, Gonzales V, Yamada M, et al. Nuclear accumulation of truncated atrophin-1 fragments in a transgenic mouse model of DRPLA. Neuron. 1999; 24(1): 27586.

185.Nucifora FC, Jr, Sasaki M, Peters MF, Huang H, Cooper JK, Yamada $\mathrm{M}$, et al. Interference by huntingtin and atrophin-1 with cbp-mediated transcription leading to cellular toxicity. Science. 2001; 291(5512): 2423-8.

186. Truant R. Nucleocytplasmic Shuttling of Huntingtin and Huntington's Disease. Clin. Neuro. Res. 2003; 3: 157-164.

187. Yamamoto A, Lucas JJ, Hen R. Reversal of neuropathology and motor dysfunction in a conditional model of Huntington's disease. Cell. 2000; 101(1): 57-66.

188.Martin-Aparicio E, Yamamoto A, Hernandez F, Hen R, Avila J, Lucas JJ. Proteasomal-dependent aggregate reversal and absence of cell death in a conditional mouse model of Huntington's disease. J Neurosci. 2001; 21(22): 8772-81.

189.Caplen NJ. RNAi quashes polyQ. Nat Med. 2004; 10(8): 775-6.

190.Xia H, Mao Q, Eliason SL, Harper SQ, Martins IH, Orr HT, et al. RNAi suppresses polyglutamine-induced neurodegeneration in a model of spinocerebellar ataxia. Nat Med. 2004; 10(8): 816-20.

191.Li Y, Yokota T, Matsumura R, Taira K, Mizusawa H. Sequencedependent and independent inhibition specific for mutant ataxin3 by small interfering RNA. Ann Neurol. 2004; 56(1): 124-9.

192. Tomar RS, Matta H, Chaudhary PM. Use of adeno-associated viral vector for delivery of small interfering RNA. Oncogene. 2003; 22(36): 5712-5.

193.Azzouz M, Kingsman SM, Mazarakis ND. Lentiviral vectors for treating and modeling human CNS disorders. J Gene Med. 2004; 6(9): 951-62. 